\title{
Palaeoenvironments during MIS 3 and MIS 2 inferred from lacustrine intercalations in the loess-palaeosol sequence at Bobingen (southern Germany)
}

\author{
Christoph Mayr ${ }^{1,2,3}$, Renate Matzke-Karasz ${ }^{2,3}$, Philipp Stojakowits ${ }^{4}$, Sally E. Lowick ${ }^{5}$, Bernd Zolitschka ${ }^{6}$, \\ Tanja Heigl ${ }^{2}$, Richard Mollath ${ }^{1}$, Marian Theuerkauf ${ }^{1}$, Marc-Oliver Weckend ${ }^{2}$, Rupert Bäumler ${ }^{1}$, and \\ Hans-Joachim Gregor ${ }^{7}$ \\ ${ }^{1}$ Institute of Geography, Friedrich-Alexander-Universität Erlangen-Nürnberg, \\ Wetterkreuz 15, 91058 Erlangen, Germany \\ ${ }^{2}$ Palaeontology and Geobiology, Earth and Environmental Sciences, \\ Ludwig-Maximilians-Universität München, 80333 München, Germany \\ ${ }^{3}$ GeoBio-Center, Ludwig-Maximilians-Universität München, 80333 München, Germany \\ ${ }^{4}$ Institute of Geography, Universität Augsburg, Alter Postweg 118, 86135 Augsburg, Germany \\ ${ }^{5}$ Institute for Geological Sciences, Universität Bern, Baltzerstrasse 1+3, 3012 Bern, Switzerland \\ ${ }^{6}$ Universität Bremen, Institute of Geography, Geomorphology and Polar Research (GEOPOLAR), \\ Celsiusstr. 2, 28359 Bremen, Germany \\ ${ }^{7}$ Daxerstr. 21, 81240 Olching, Germany
}

Correspondence: Christoph Mayr (christoph.mayr@fau.de)

Relevant dates: $\quad$ Published: 20 December 2017

How to cite: $\quad$ Mayr, C., Matzke-Karasz, R., Stojakowits, P., Lowick, S. E., Zolitschka, B., Heigl, T., Mollath, R., Theuerkauf, M., Weckend, M.-O., Bäumler, R., and Gregor, H.-J.: Palaeoenvironments during MIS 3 and MIS 2 inferred from lacustrine intercalations in the loess-palaeosol sequence at Bobingen (southern Germany), E\&G Quaternary Sci. J., 66, 73-89, https://doi.org/10.5194/egqsj-66-73-2017, 2017.

Abstract: $\quad$ Recently exposed loess-palaeosol sequences in the northern Alpine foreland close to Bobingen (southern Germany) were investigated with a multi-proxy approach combining isotopic, geochemical, lithological, and micropalaeontological methods. Luminescence ages date the sections into the Middle and Upper Würmian periods corresponding to Marine Isotope Stages 3 and 2. A gleyic soil horizon at the base was dated to $45 \mathrm{ka}$ and provided a palynoflora dominated by Poaceae, Cyperaceae, and Pinus, as well as frequent aquatic taxa. Lacustrine conditions prevailed after the gley formation until $30 \mathrm{ka}$, providing a comparatively diverse lacustrine fauna dominated by aquatic gastropods and the ostracod species Candona candida. At the transition to the Upper Würm, climatic conditions became harsh, indicated by accelerated deposition of more coarse-grained loess, organic geochemical indicators, and scarceness of biotic remains. Two tundra-gley horizons in the Upper Würm point to short phases of climatic amelioration with higher humidity also evidenced by reoccurrence of ostracod and aquatic gastropod remains. We propose that these climatic ameliorations were coincident with the Greenland interstadials 4 and 2 . 
Kurzfassung:

Unlängst bei Bobingen (Bayern) im nördlichen Voralpenland aufgeschlossene Löß-PaläobodenSequenzen wurden mit einem Multi-Proxy-Ansatz untersucht, der mikropaläontologische, geochemische, lithologische und isotopische Methoden umfasste. Mit Hilfe von LumineszenzDatierungen wurden die Profile in das Mittlere und Obere Würm, entsprechend dem marinen Isotopenstadium (MIS) 3 und 2, datiert. Ein gleyartiger Horizont an der Basis datierte auf $45 \mathrm{ka}$ und lieferte eine Pollenflora, die von Poaceae, Cyperaceae und Pinus, aber auch häufigen aquatischen Taxa dominiert wird. Lakustrine Verhältnisse herrschten nach der Bildung des Gleys bis $30 \mathrm{ka}$. Diese Ablagerungen lieferten eine vergleichsweise artenreiche lakustrine Fauna, in der aquatische Gastropoden und die Ostracodenart Candona candida vorherrschen. Am Übergang zum Oberen Würm setzten strengere klimatische Bedingungen ein, die sich durch vermehrte Ablagerung von grobkörnigerem Löß, weitgehendes Fehlen von biotischen Resten und in den organischgeochemischen Indikatoren zeigen. Zwei Tundragley-Horizonte im Oberen Würm deuten auf kurze Phasen mit milderem Klima hin, wobei in diesen die Wiederkehr von Ostracoden und aquatischen Gastropoden auch auf höhere Feuchtigkeit hinweist. Diese Phasen kurzfristiger Klimaverbesserung entsprechen wahrscheinlich den Grönland-Interstadialen 4 und 2.

\section{Introduction}

Despite a long research history, starting with Penck (1882) and Penck and Brückner (1901-1909), large gaps still exist in our knowledge of glacial palaeoenvironments in the northern Alpine foreland mainly due to the fragmentary and discontinuous preservation of natural climate archives in this region. In particular, sedimentary records of the last glacial period, the Würm, often have numerous hiatuses caused by subsequent glaciofluvial erosion in the Alps and their foreland (Doppler et al., 2011). Recent studies of speleothems and inner-Alpine lacustrine sequences (Moseley et al., 2014; Heiri et al., 2014, and references therein) have substantially enlarged our knowledge of regional Würmian climate and environments. Loess sequences provide another archive of Quaternary palaeoenvironments in southern Germany, which has been investigated chronostratigraphically and sedimentologically in detail since the 1950s (e.g. Brunnacker, 1953). Typical successions of palaeosoils and loess (loess-palaeosol sequences, LPS) from central Europe were described and allowed us to establish a pedo- and lithostratigraphic framework (Zöller and Semmel, 2001; Terhorst et al., 2015). However, incomplete preservation due to hiatuses hamper the comparison of LPS from central Europe and require compilations of loess stratigraphies from multiple sites (Lehmkuhl et al., 2016). In the last decade, multi-proxy investigations provided new insights into palaeoenvironmental conditions during the last glacial period in the western European loess belt (Antoine et al., 2009, 2013). Here, we present a recently exposed LPS close to the town of Bobingen in the northern Alpine foreland of southern Germany. Although the stratigraphy of adjacent profiles was investigated in detail previously, the new section is exceptional due to the occurrence of lacustrine intercalations in the loess sequence. Thus, the Bobingen site provides one of the very few lacustrine records in a loess landscape of Middle Würmian age in the Northern Alps and their foreland (Starnberger et al., 2009; Heiri et al., 2014). Additionally, multi-proxy approaches for palaeoenvironmental reconstruction were not yet frequently applied to these LPS in the northern Alpine foreland, despite the fact that they provide valuable new insights to their interpretation (e.g. Antoine et al., 2013). Detailed micropalaeontological, isotopic, and geochemical methods were combined at the Bobingen site. Together with new optically stimulated luminescence (OSL) dates, this multiproxy approach aims to shed new light on the palaeoclimate and palaeoenvironment during the Middle and Upper Würm in the northern foreland of the Alps.

\section{Site description}

The main terraces alongside the river Lech are a classical area of loess research in southern Germany for more than two decades (Aktas and Frechen, 1991; Schreiber and Müller, 1991; Bibus, 1995). They are subdivided into three areas locally called (from north to south) Rain, Langweid, and Augsburg high terraces (Schaefer, 1957; Scheuenpflug, 1979). The uppermost gravel units forming these terraces were dated to the penultimate Rissian glaciation in the Augsburg high terrace corresponding to Marine Isotope Stage (MIS) 6 (Frechen, 1999). Recent luminescence dating extends the ages for the basal unit of these gravel deposits to MIS 7 and older in the Langweid and Rain high terraces, whereas the age span for the top gravel unit was confirmed (Schielein et al., 2015). Previous studies described the lithological and pedogenic features of the loess sequence on the Augsburg high terrace and provided the first luminescence ages, placing it in the Würm (BeckerHaumann and Frechen, 1997; Frechen, 1999).

The new site studied here was exposed in a gravel pit close to Bobingen $\left(48.277^{\circ} \mathrm{N}, 10.852^{\circ} \mathrm{E} ; 521 \mathrm{~m}\right.$ a.s.l. $)$ and 
is situated on the Augsburg high terrace (Fig. 1). On this terrace, glaciofluvial gravel and sand deposits are covered by a locally preserved and then prominent reddish ("rubified") palaeosoil and around $5 \mathrm{~m}$ of loessic sediments exposed in gravel pits of the company Lauter Sand Kies Beton $\mathrm{GmbH}$ east of Bobingen (Fig. 2). Previous OSL dating in a gravel pit a few hundreds of metres west of the outcrops described here suggested Mid-Würmian age of the loess deposits and Rissian age for the gravel deposit, while the rubified palaeosoil was attributed to the Eemian (BeckerHaumann and Frechen, 1997). The locality recently came into the focus of research again because of the discovery of megamammal teeth and bone fragments (Coelodonta antiquitatis, Elephas primigenius, Equus ferus) in the loessic deposits and channel fillings cut into the underlying gravel deposits (Gregor, 2012). In the course of these findings, the loess sections were reinvestigated, leading to the discovery of lacustrine deposits with aquatic gastropods, ostracods, and micromammal remains in an area named Gewanne II (Fig. 2). A detailed description of the stratigraphic succession, its fossil content, and facies is the topic of this study.

\section{Material and methods}

\subsection{Sampling and fieldwork}

The loess sections in the gravel pit at Bobingen were studied and sampled between the years 2011 and 2013. The investigated sections were 3 to $60 \mathrm{~m}$ apart from each other (Fig. 3). Sections I and II were sampled in 2011 for micropalaeontological and isotopic analyses; section IV was analysed in 2012 for XRF, grain-size, bulk geochemical, and pollen analyses; and section III was sampled in 2013 for OSL dating. The sections were linked using sedimentological and pedogenic marker layers (Fig. 3). The colour of the samples was determined using the Munsell Soil Color Charts at the fresh outcrops (Munsell Color, 2000).

\subsection{Grain size and carbonate contents}

About 10 to $20 \mathrm{~g}$ of each sample was weighed for grainsize determination. Carbonate content was removed prior to analysis with $10 \% \mathrm{HCl}$. Decalcification could have changed the original grain-size composition of clastic components. However, this was unavoidable as carbonate particles were partly of pedogenic and biogenic origin. After decalcification, samples were repeatedly suspended with deionized water and centrifuged until achieving a neutral $\mathrm{pH}$. Then they were dried at $105^{\circ} \mathrm{C}$. The decalcified samples were dispersed in $80 \mathrm{~mL} \mathrm{Na} \mathrm{P}_{2} \mathrm{O}_{7}$ solution $(0.1 \%)$ and shaken overnight. Afterwards, the coarse grain-size fractions were separated with a nested column of sieves with mesh widths of 2000, 630, 200, and $63 \mu \mathrm{m}$. Coarse fractions were determined by the weight of the sieve residues after drying. Silt and clay fractions $(<63 \mu \mathrm{m})$ were collected, resuspended,
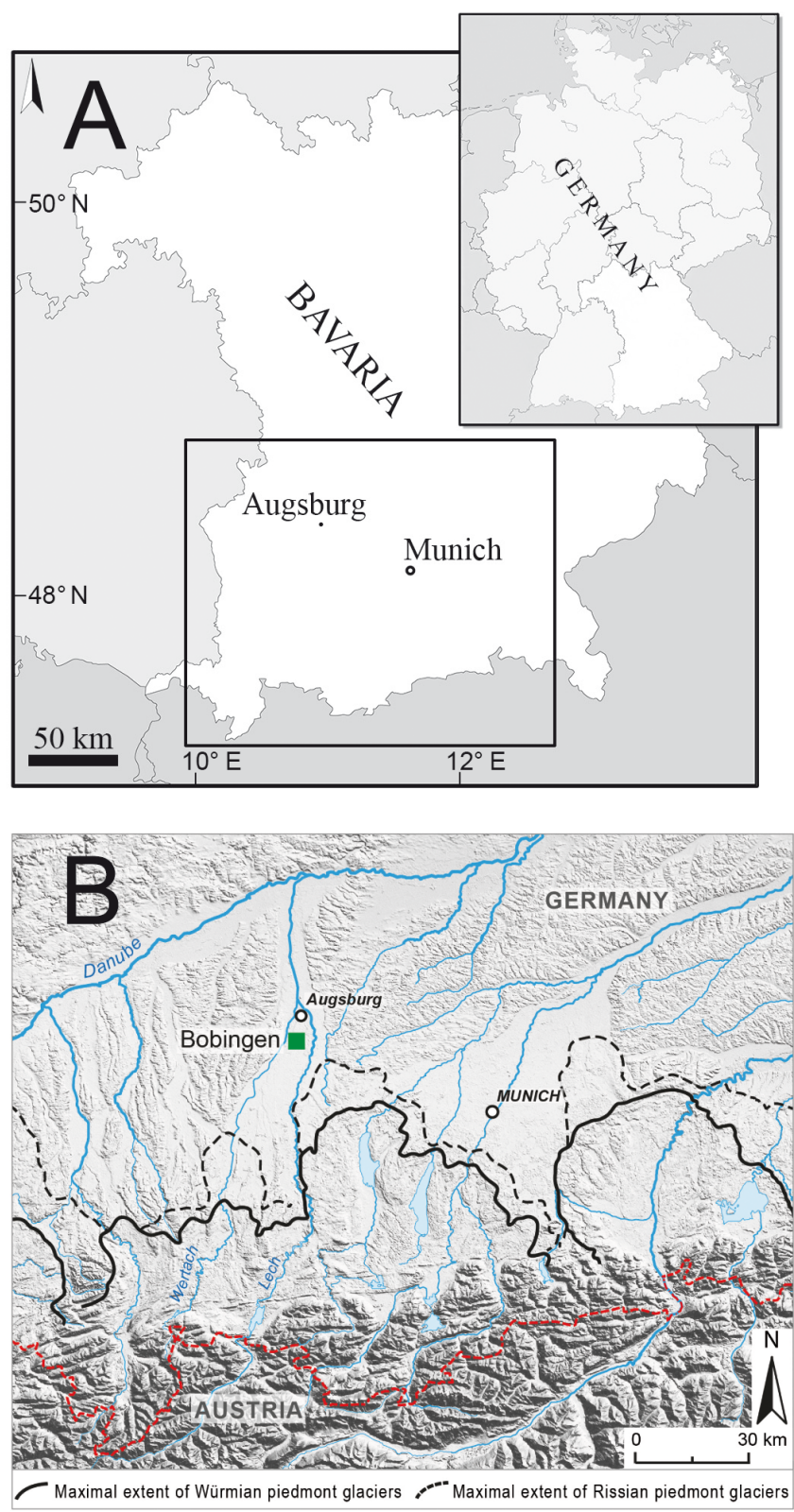

Figure 1. (a) Maps of Germany and Bavaria; the box indicates the inset shown in panel (b). (b) Research area in the southern Bavarian Alpine foreland showing the maximal extents of Würmian and Rissian piedmont glaciers and the location of Bobingen. Base map modified from Scilands GmbH. The red line indicates the GermanAustrian border.

and analysed using an X-ray absorption-based particle-size analyser (SediGraph III plus, Micrometrics).

The carbonate content of the samples was determined by measuring the partial pressure of $\mathrm{CO}_{2}$ evolved in a closed volume after having added $6 \mathrm{~N} \mathrm{HCl}(25 \%)$ in excess to $0.70 \mathrm{~g}$ of the homogenized sample. For these analyses a sealed container was used, described as Karbonat-Bombe (Müller and Gastner, 1971). 


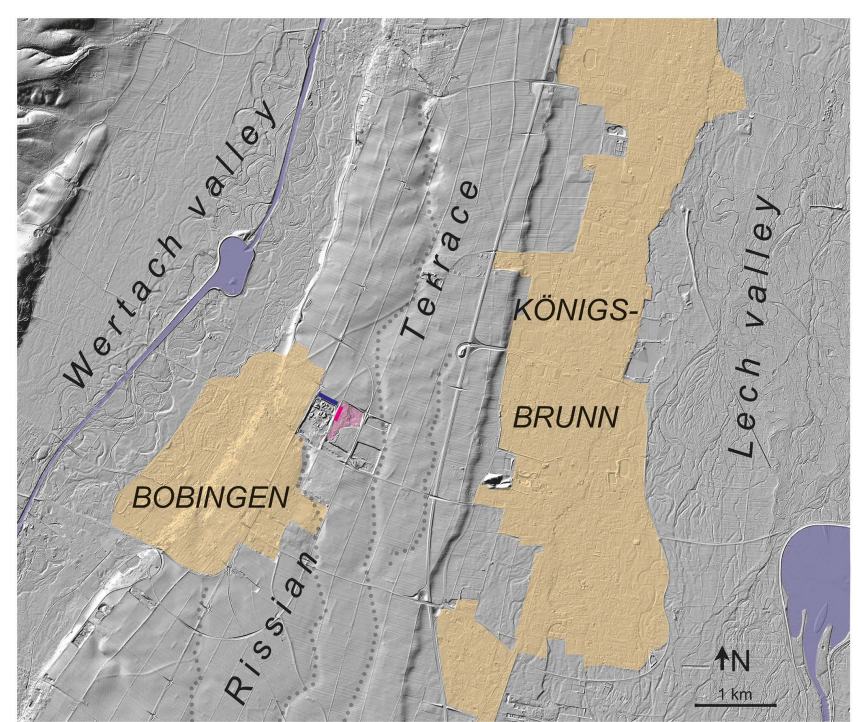

Figure 2. Digital elevation model (geographic basic data: Bayerische Vermessungsverwaltung) of the area around Bobingen showing the Rissian terrace surrounded by the lower terraces of the River Wertach to the west and the River Lech to the east. The present courses of these rivers are outlined in blue and the settlements of Bobingen and Königsbrunn in beige. The position of the investigated gravel pit and the loess profile are indicated by the pink area and line (Gewanne II), respectively. The blue line indicates the position of the profiles presented in Becker-Haumann and Frechen (1997). Dotted lines highlight inactive fluvial channels on the Rissian terrace, presumably originating from before the Last Glacial (Würmian) Maximum.

\subsection{Organic geochemistry}

A representative mixed sample from each unit of section I was homogenized with a mortar and pestle. An aliquot of $2-50 \mathrm{mg}$ of the homogenized sample was weighed in tin capsules for determination of total carbon (TC) and nitrogen (TN) content. About 50-60 mg of another aliquot was weighed into a silver capsule and decalcified with $5 \%$ and subsequently $20 \% \mathrm{HCl}$ at $70^{\circ} \mathrm{C}$ on a heating plate for total organic carbon (TOC) contents and organic carbon isotope ratios $\left(\delta^{13} \mathrm{C}_{\mathrm{org}}\right)$. The capsules were combusted in a continuous helium flow in an elemental analyser (NC2500, Carlo Erba) linked to an isotope-ratio mass spectrometer (DeltaPlus, Thermo-Finnigan). The carbon and nitrogen mass percentages were calculated from sample-peak areas using the elemental standards atropine and cyclohexanone2,4-dinitrophenylhydrazone for calibration. Low TOC and TN contents were accounted for by calibrating with appropriately low weights of the standards. Total inorganic carbon (TIC) was calculated as difference between TC and TOC. All element content values are reported in \% relative to dry mass. TOC / TN ratios are given as molar ratios. $\delta^{13} \mathrm{C}_{\text {org }}$ values are given in \%o according to the formula $\delta^{13} \mathrm{C}=\left(R_{\text {sample }} / R_{\text {standard }}-1\right) \times 1000$, where $R$ is the isotope ratio $\left({ }^{13} \mathrm{C} /{ }^{12} \mathrm{C}\right)$ and Vienna Pee Dee Belemnite (VPDB) represents the international standard. The precision of the analyses calculated from lab standards routinely analysed together with the samples was better than $0.2 \%$ for $\delta^{13} \mathrm{C}_{\text {org }}$ analyses and about $5 \%$ for the TN and TOC determinations.

\subsection{Palaeobiological methods (palynology, ostracods, gastropods)}

About $1000-10000 \mathrm{~cm}^{3}$, depending on the microfossil content, of sediment from all lithological units was taken from sections I and II for micropalaeontological studies. The air-dried samples were dispersed in deionized water for $24 \mathrm{~h}$ and the suspension was sieved with tap water through sieves with mesh widths of 500 and $100 \mu \mathrm{m}$. If the suspension was incomplete, the dispersion procedure was repeated. Finally the sieve residues were rinsed with deionized water and dried for $74 \mathrm{~h}$ at $40^{\circ} \mathrm{C}$. The fossil remains, in particular molluscs and ostracods, were selected from the different size fractions using reflected-light microscopes (Leica MS 5 and Leica MZ6). For taxonomic identification of molluscs Zettler and Glöer (2006), Boschi (2011), Glöer and Meier-Brook (2003), Ložek (1964), and WelterSchultes (2012) were used. Ostracods were identified using Fuhrmann (2012), Griffiths et al. (1993), Griffiths and Holmes (2000), and Meisch (2000). The classification of secondary carbonates followed Barta (2011) and Koeniger et al. (2014).

For pollen analyses only the lowest part of section IV was suitable, as it was deposited under reducing conditions indicated by darkish and bluish-grey colours in contrast to the overlying strata. The loessic upper part of the section was not investigated as oxic conditions commonly prevent the conservation of sufficient amounts of pollen (Moore et al., 1991). The pollen samples were taken from a sediment monolith of $52 \mathrm{~cm}$ length subsampled in the laboratory at $2 \mathrm{~cm}$ intervals. Each subsample contained $5 \mathrm{~cm}^{3}$. The samples were first sieved to get the grain fraction smaller than $150 \mu \mathrm{m}$. Afterwards, they were treated with warm $\mathrm{NaOH}$ to deflocculate clays, with $\mathrm{ZnCl}_{2}$ to remove silicates by heavy liquid separation, and finally by acetolysis following standard procedures (Faegri and Iversen, 1989; Moore et al., 1991). Pollen grains were identified at magnifications of 400 and 1000 by comparison with the pollen reference collection at the Department of Geography (University of Augsburg), the pollen key of Beug (2004), and primary literature for specific taxa (Clarke et al., 2001; Blackmore et al., 2003).

\subsection{XRF scanning}

For XRF scanning air-dried samples, each covering $10 \mathrm{~cm}$ of stratigraphic height in sediment section IV, were homogenized using a planetary mill (Pulverisette 5, Fritsch). Thereafter, $1 \mathrm{~cm}^{3}$ of the powdered samples was filled 

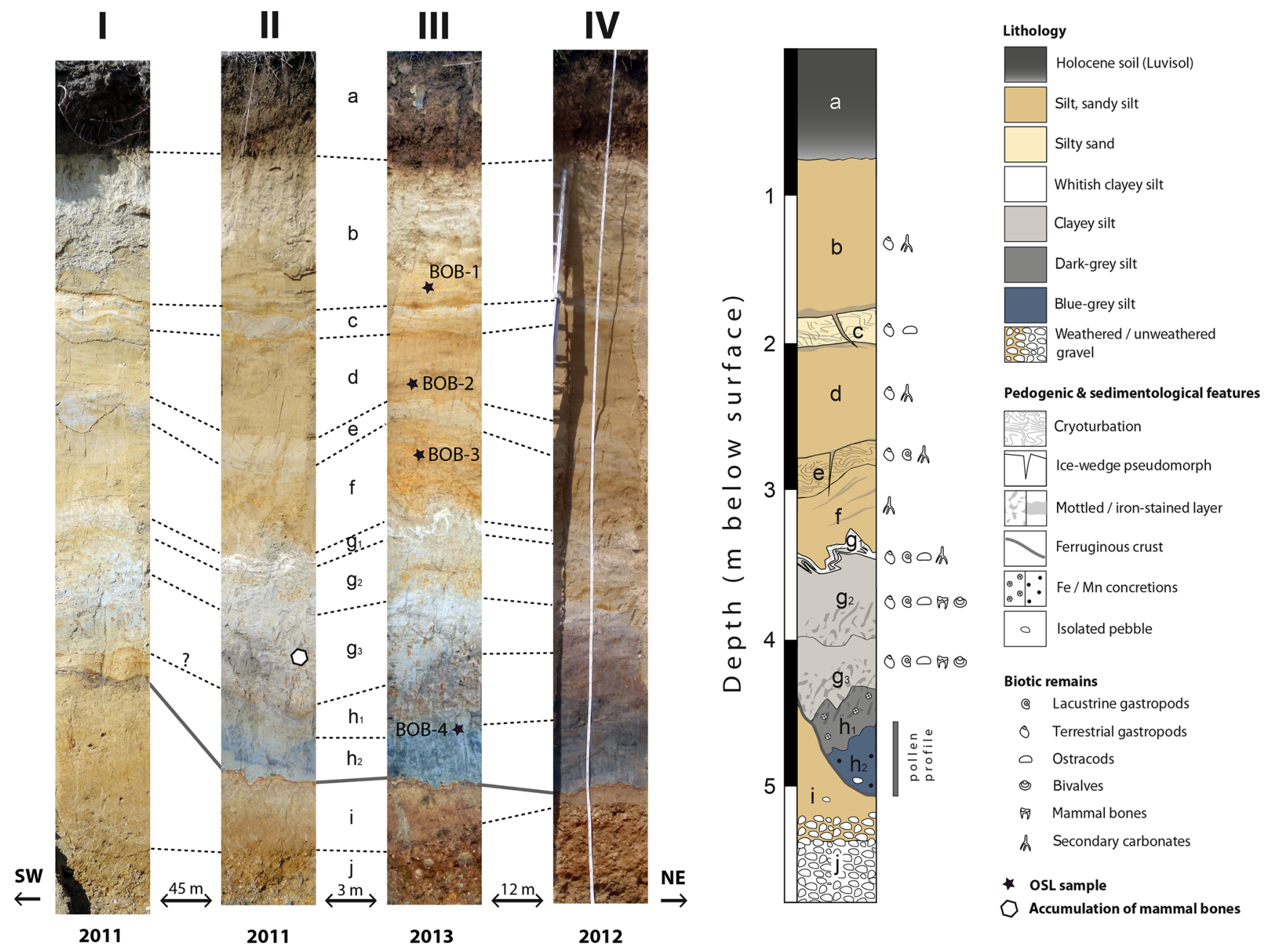

Figure 3. Photographs of the four loess sections I to IV sampled in the years 2011 to 2013 in Bobingen. The idealized composite profile summarizes the main sedimentological and palaeontological features observed. The positions of the OSL samples (labelled BOB-1 to BOB-4) are indicated in III and the position of accumulated micromammal bones in II. Sedimentary and pedogenic units are labelled a to $\mathrm{j}$.

into sample cups and compacted manually. Samples were mounted equidistantly in a tray and analysed with an XRF core scanner (ITRAX, Cox Analytics) equipped with a Mo tube (Ohlendorf, 2017). Each sample was analysed at a constant exposure time of $100 \mathrm{~s}$ and a power setting of $30 \mathrm{kV}$ and $20 \mathrm{~mA}$. The XRF core scanner produces single dispersive energy spectra for each point measured. Unlike for conventional XRF measurements, instrumental calibrations are not routine. Counts of elements $\mathrm{Al}$ to $\mathrm{U}$ in the periodic system were registered and calculated by mathematical fitting of peak area integrals for the measured spectra using the software Q-Spec (Croudace et al., 2006). Here, we only present the good-quality elemental records obtained for $\mathrm{K}$, $\mathrm{Ca}, \mathrm{Fe}$, and Ti. These elements appear to be most indicative for the pedogenic and sedimentological processes of interest. Problems with elemental scattering can occur with variations in water content and grain size (both excluded here as all samples were dried and ground before analyses) and content of organic matter. To take care of such matrix effects as well as of sample inhomogeneity, all values (given in counts per second: cps) were normalized by dividing them with the respective coherent radiation (coh).

\subsection{OSL dating}

Four samples, labelled BOB-1 to BOB-4 from top to bottom, were taken for OSL dating with aluminium tubes $(35 \mathrm{~cm}$ length, inner diameter $5 \mathrm{~cm})$ from section III. All sample preparations and measurements were conducted at the Institute for Geological Sciences of the University of Bern. The outer layers of the OSL samples that may have been exposed to daylight were removed and all further work was carried out under subdued orange light in the laboratory. Samples underwent fine-grain preparation, where grains were treated with $32 \% \mathrm{HCl}$ to remove carbonates, $30 \%$ hydrogen peroxide to remove any organic component, and 
sodium oxalate to prevent aggregation of grains. To isolate the polymineral fine-grain fraction $(4-11 \mu \mathrm{m})$, samples were settled in Atterberg cylinders utilizing Stokes' law. To obtain a quartz fraction, a portion of the polymineral fraction was immersed in $31 \%$ hydrofluorosilicic acid for 10 days, followed by rinsing with $32 \% \mathrm{HCl}$ to remove fluorides. Grains were settled in acetone on stainless steel discs. All measurements were made on automated Ris $\varnothing$ TL/OSL DA20 readers, fitted with an EMI 9235QA photomultiplier tube. Optical stimulation of quartz (OSL) was performed at $90 \%$ power using blue LEDs $(470 \pm 30 \mathrm{~nm} ; \sim 41$ and $48 \mathrm{~mW} \mathrm{~cm}^{-2}$ maximum power), and the OSL signal was detected through $7.5 \mathrm{~mm}$ of a Hoya U-340 transmission filter. For each sample, 400-500 $\mathrm{g}$ of material from the surrounding sediment was used for dose rate calculations, and the specific activities of $\mathrm{U}$, Th, and $\mathrm{K}$ were determined using highresolution gamma spectrometry (Preusser and Kasper, 2001). No evidence for radioactive disequilibrium in the uranium decay chain was found using the approach described by Zander et al. (2007).

Water contents were determined on fresh samples. About $20 \%$ was added to these values to account for possible desiccation due to short time exposure of the outcrop. All estimated dose $\left(D_{\mathrm{e}}\right)$ measurements were made using a modified version of the single aliquot regenerative (SAR) dose protocol (Murray and Wintle, 2000; described in Table 1). Dose recovery and preheat tests were conducted using temperatures from 220 to $280^{\circ} \mathrm{C}$ (Fig. 4a) in order to identify the appropriate temperature at which $D_{\mathrm{e}}$ was seen to be independent. A preheat temperature of $260^{\circ} \mathrm{C}$ was chosen for all quartz measurements. This was held for $10 \mathrm{~s}$ and also applied to all test doses. For dose recovery tests, a laboratory dose of $\sim 150 \mathrm{~Gy}$ was given, and all samples were able to recover the dose within $10 \%$ of unity for all temperatures (Fig. 4b). Recycling ratios confirmed the ability of the measurement sequence to correct for any change in sensitivity of the sample over time (Wintle and Murray, 2000). Recuperation of the signal following a zero regenerative dose was monitored, and this did not exceed $5 \%$ of the natural signal for most aliquots. The response of the quartz fraction to IR stimulation was used to detect any feldspar contamination by determining a reverse IR depletion ratio (Duller, 2003). IR stimulation for $100 \mathrm{~s}$ at $50^{\circ} \mathrm{C}$ was inserted before all measurements, but prior to that for the second recycle point. The IR depletion ratio remained above 0.90 for all aliquots and confirmed that the quartz signal does not suffer adverse effects from feldspar contamination. Mean $D_{\mathrm{e}}$ values were calculated using the Central Age Model (Galbraith et al., 1999).

An example of the OSL decay curve for sample BOB1 is shown in Fig. 5, and confirms that the quartz signal displayed a rapid decay, indicating that it is dominated by the fast component. Quartz $D_{\mathrm{e}}$ values were determined using the first $0.4 \mathrm{~s}$ of the OSL decay curve and subtraction of a late background calculated using the last $40 \mathrm{~s}$ of a $60 \mathrm{~s}$
Table 1. SAR protocol modified from Murray and Wintle (2003) applied to the fine-grained quartz fraction of all samples. $L$ is the stimulation of the natural signal $(n)$ and regeneration doses $(x) ; T$ is the subsequent test dose.

\begin{tabular}{lll}
\hline Step & Treatment & Observed \\
\hline 1 & Give dose $^{\mathrm{a}}$ & \\
2 & Preheat $260^{\circ} \mathrm{C}$ for $10 \mathrm{~s}$ & \\
$3^{\mathrm{b}}$ & IR stimulation for $100 \mathrm{~s}$ at $50{ }^{\circ} \mathrm{C}$ & \\
4 & Blue stimulation for $60 \mathrm{~s}$ at $125^{\circ} \mathrm{C}$ & $L_{n}$ or $L_{x}$ \\
5 & Give test dose & \\
6 & Preheat $260^{\circ} \mathrm{C}$ for $10 \mathrm{~s}$ & \\
7 & Blue stimulation for $60 \mathrm{~s}$ at $125^{\circ} \mathrm{C}$ & $T_{n}$ or $T_{x}$ \\
8 & IR stimulation for $100 \mathrm{~s}$ at $50^{\circ} \mathrm{C}$ & \\
9 & Return to 1 & \\
\hline
\end{tabular}

${ }^{\mathrm{a}}$ For $L_{n}$ this is $0 .{ }^{\mathrm{b}}$ Not applied for second recycle point.

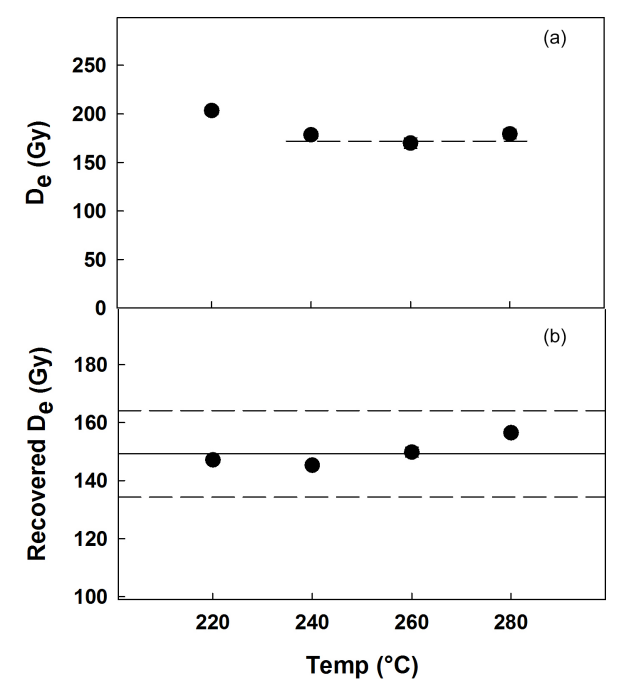

Figure 4. Preheat (a) and dose recovery (b) tests applied to BOB4. For the dose recovery test, a regenerative dose of $\sim 150 \mathrm{~Gy}$ was applied. Dashed lines represent $10 \%$ errors.

stimulation. The quartz OSL dose response fit best to a saturating exponential function, which was used to determine $D_{\mathrm{e}}$ values.

\section{Results}

\subsection{Stratigraphy and lithology}

Although the lithological features changed along the southwest-northeast-oriented transect of the sequence, several sedimentary and pedogenic units could be unambiguously traced through the sections and were labelled a to $\mathrm{j}$ (Fig. 3). Unit a represents the Holocene soil that developed above the Würmian loess. The $80 \mathrm{~cm}$ thick soil $\mathrm{c}$ is a Luvisol (Parabraunerde according to German soil classification) characterized by a Bt horizon. Below the 


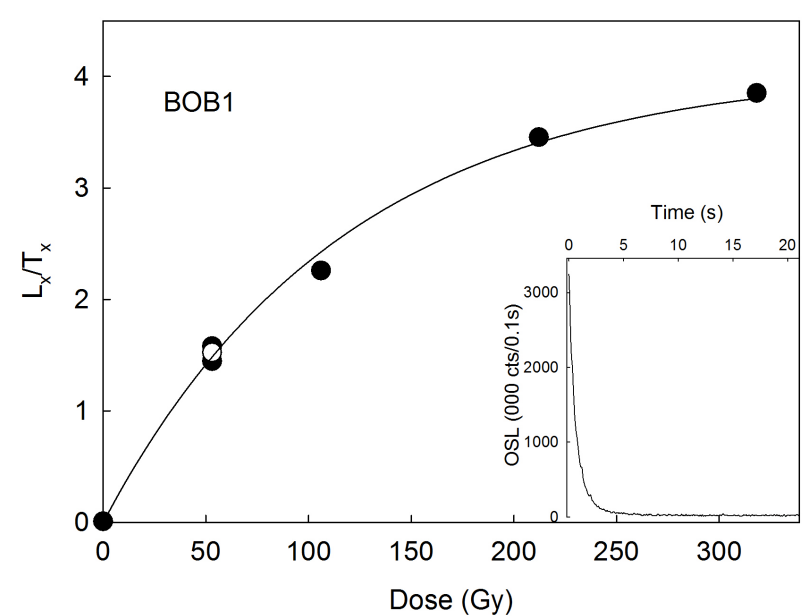

Figure 5. Dose response curve for sample BOB-1 together with the decay curve of a natural signal (inset). Empty circle indicates the recycle dose point. This behaviour is representative for all samples.

Holocene soil, a succession of alternating yellowish silty to pale-ochre silty-sandy loess horizons (b-f in Fig. 3) is exposed. The uppermost of these horizons (b) consists of $100-120 \mathrm{~cm}$ thick yellowish-ochre sandy silt (Munsell soil colour $2.5 \mathrm{Y} 6 / 4$ ) and contains a few gastropod remains and secondary carbonates. The secondary carbonates were classified as combined hypocoatings and carbonate coatings. The underlying horizon c consists of leached yellowishgrey silty sand $(2.5 \mathrm{Y} 6 / 3)$, which is sandwiched by ironstained layers. It contains very few gastropods and ostracods. The thickness of layer $\mathrm{c}$ is $15-20 \mathrm{~cm}$ and ice wedge pseudomorphs of a few decimetre length cut through it from its surface. The wavy structure of this horizon points to cryoturbation. Horizon $\mathrm{d}$ is $60-80 \mathrm{~cm}$ thick and consists of yellowish-ochre sandy silt (2.5 Y6/4). It contains hypocoatings and a few gastropods. The $20-30 \mathrm{~cm}$ thick horizon e below resembles horizon $\mathrm{c}$ in colour $(2.5 \mathrm{Y} 6 / 3)$ and sedimentary features. It consists of leached brownish grey silt, shows evidences of cryoturbation, and contains a combined form of hypocoatings and carbonate coatings (Fig. 9r), gastropods, as well as ice wedge pseudomorphs. Horizon $\mathrm{f}$ is a yellowish-ochre (2.5 Y6/4), 40-60 cm thick silt that partially shows weak stratification caused by iron staining. Except for combined hypocoatings and carbonate coatings no macroscopic biotic remains were found. A comparatively high fossil content characterizes horizon $\mathrm{g}$ with a thickness of about $1 \mathrm{~m}$. It can be subdivided into three layers ( $g_{1}, g_{2}$, and $g_{3}$ from top to bottom), differing in colour, but all three contain a comparatively diverse ostracod and lacustrine mollusc fauna in addition to terrestrial gastropods. The topmost layer $\mathrm{g}_{1}$ is a pale-white (2.5 Y8/2) silt, strongly deformed by cryoturbation. It contains earthworm biospheroids (Fig. 9s) and few hypocoatings. Unit $\mathrm{g}_{2}$ consists of greyish-brownish silt with mottled colouration (2.5 Y5/6 and $2.5 \mathrm{Y} 5 / 1)$. Unit $\mathrm{g}_{3}$ consist of light-grey silt (2.5 Y $6 / 2$ and $2.5 \mathrm{Y} 6 / 4)$.

Unit $\mathrm{h}$ is characterized by absence of macroscopic biotic remains, low carbonate and clay contents, and a predominance of the medium-sized silt fraction $(6.3-20 \mu \mathrm{m})$. It has a thickness of about $70 \mathrm{~cm}$ and was subdivided into an upper dark-grey $(2.5 \mathrm{Y} 5 / 3)$ layer with rust stains $\left(\mathrm{h}_{1}\right)$ and a lower bluish-grey $(4 / 5 \mathrm{GY})$ part $\left(\mathrm{h}_{2}\right)$ in the northern sections (II-IV; Fig. 3). The lower limit of $\mathrm{h}_{2}$ is a ferruginous crust with an ascending position from north to south. In the southernmost section I the grey colour disappears completely due to oxidation and horizon $\mathrm{h}$ cannot be distinguished optically from the basal layer i. In other sections (II-IV), the basal layer i consists of brownish silt (7.5 YR 4/4) above the basal brown loamy weathered gravel (layer j, 7.5 YR 4/4).

\subsection{OSL dating and age model}

$D_{\mathrm{e}}$ values and ages are reported together with dosimetric data in Table 2. All aliquots measured passed the performance criteria, and the rapid decay of stimulation curves confirmed the identification of the fast component. When determining $D_{\mathrm{e}}$ values from quartz OSL signals, Wintle and Murray (2006) state that the calculation of uncertainties may become problematic above 2D0 (a value used to characterize $85 \%$ saturation of the signal). 2D0 was calculated by fitting dose response curves to a single saturating exponential and values ranged between 2 and $300 \mathrm{~Gy}$. All OSL ages were in stratigraphic agreement and provided ages between 20 and 50 kiloyears $(\mathrm{ka}) . D_{\mathrm{e}}$ values remained below $150 \mathrm{~Gy}$ and do not fall in a region for which methodological problems have been reported (Chapot et al., 2012; Lai, 2010; Lowick et al., 2010; Timar et al., 2010). Therefore these ages are considered reliable.

\subsection{Organic geochemistry}

The TC content varied between 0.2 and $0.3 \%$ in the lower units $\mathrm{h}$ to $\mathrm{j}$ (Fig. 6), gradually increased from unit $\mathrm{g}_{3}(1.5 \%)$ to $\mathrm{g}_{1}(6.4 \%)$, and remained at a higher level (between 6.6 and $7.4 \%)$ in the upper units. The TIC contents are only slightly less than TC values, indicating that most of the carbon is of carbonate origin and TOC contributes only a minor amount. The TOC contents were between 0.1 and $0.4 \%$ in the lower part and around $0.1 \%$ in the upper part of the section. TN correlates with TOC and $\mathrm{TN}$ values were between 0.01 to $0.02 \%$ in the upper (units $\mathrm{b}$ to $\mathrm{g}_{1}$ ) and between 0.04 and $0.06 \%$ in the lower part (units $\mathrm{g}_{2}$ to $\mathrm{j}$ ). Unit $\mathrm{g}_{3}$ had the highest TOC $(0.4 \%)$ and TN $(0.06 \%)$ contents. The $\delta^{13} \mathrm{C}_{\text {org }}$ values also show a twofold pattern. The lower part of the section has values between $-26.1 \%$ (unit $\mathrm{h}$ ) and $-24.0 \%$ (unit $\mathrm{g}_{1}$ ). The values in the upper part are around $-23.4 \%$ (units $d$ and e). TOC / TN values were rather low and varied between 4 (units $\mathrm{i}, \mathrm{j}$ ) and 9 (unit $\mathrm{g}_{3}$ ). 
Table 2. Information about dosimetry, water content, $D_{\mathrm{e}}$ values, and calculated ages.

\begin{tabular}{|c|c|c|c|c|c|c|c|c|c|c|c|}
\hline \multirow[t]{2}{*}{ Sample } & \multirow{2}{*}{$\begin{array}{l}\text { Sediment } \\
\text { depth }(\mathrm{cm})\end{array}$} & \multirow{2}{*}{$\begin{array}{l}\text { Lithological } \\
\text { unit }\end{array}$} & \multirow{2}{*}{$\begin{array}{r}\text { Grain size } \\
(\mu \mathrm{m})\end{array}$} & \multirow[t]{2}{*}{$N^{\mathrm{b}}$} & \multicolumn{3}{|c|}{ Radionuclide concentration $\left(\mathrm{Bq} \mathrm{kg}^{-1}\right)^{\mathrm{a}}$} & \multirow{2}{*}{$\begin{array}{l}\text { Dose rate } \\
\left(\mathrm{Gy} \mathrm{ka}^{-1}\right)\end{array}$} & \multirow{2}{*}{$\begin{array}{r}\text { Water } \\
(\%)\end{array}$} & \multirow[t]{2}{*}{$D_{\mathrm{e}}(\mathrm{Gy})$} & \multirow[t]{2}{*}{ Age $(\mathrm{ka})^{\mathrm{C}}$} \\
\hline & & & & & ${ }^{266} \mathrm{Ra}$ & ${ }^{232} \mathrm{Th}$ & ${ }^{40} \mathrm{~K}$ & & & & \\
\hline BOB-1 & 200 & $\mathrm{~b}$ & $4-1$ & 7 & $26.9 \pm 0.4$ & $18.8 \pm 0.8$ & $209.9 \pm 5.3$ & $1.7 \pm 0.2$ & 15 & 4 & 2.7 \\
\hline BOB-2 & 295 & $\mathrm{~d}$ & 4 & 6 & $26.4 \pm 0.3$ & $16.4 \pm 0.3$ & $167.2 \pm 5.7$ & $1.5 \pm$ & 15 & .2 & 28.5 \\
\hline BOB-3 & 345 & $\mathrm{f}$ & 4 & 7 & $29.0 \pm 0.6$ & $19.6 \pm 0.5$ & $196.0 \pm 3.0$ & $1.6 \pm 0.2$ & 25 & $46.3 \pm 1.1$ & $29.6 \pm 3.8$ \\
\hline BOB-4 & 545 & $\mathrm{~h}_{1} / \mathrm{h}_{2}$ & $4-11$ & 7 & $45.5 \pm 0.9$ & $47.7 \pm 0.7$ & $451.8 \pm 5.2$ & $2.8 \pm 0.3$ & 35 & $124.4 \pm 1.9$ & $45.2 \pm 5.4$ \\
\hline
\end{tabular}

${ }^{a}$ Concentrations were converted to infinite matrix dose using the standard conversion factors of Adamiec and Aitken (1998). Cosmic radiation contribution was calculated using the present-day sample burial depth following Prescott and Hutton (1994), and attenuation factors were taken from Mejdahl (1987). ${ }^{\mathrm{b}} \mathrm{N}$ is the number of individual aliquots contributing to the $D_{\mathrm{e}}$ value. ${ }^{\mathrm{c}}$ Errors on OSL ages represent 1 standard error.

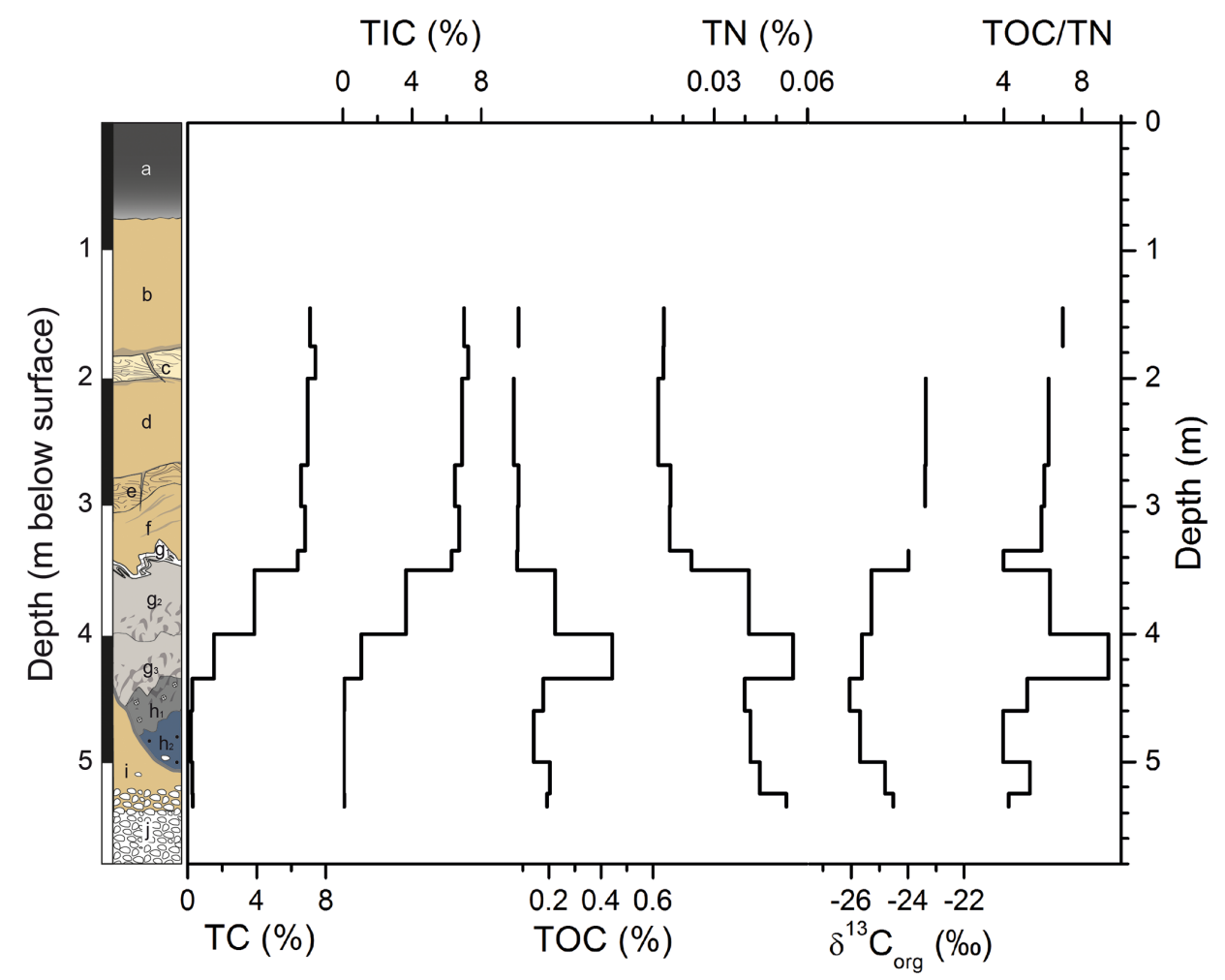

Figure 6. Organic geochemistry and isotope data from section I. Missing values are indicated by gaps.

\subsection{Inorganic geochemistry and grain-size distribution}

Results of carbonate-content, XRF, and grain-size analyses are shown in Fig. 6. An intense decalcification, represented by low carbonate contents $(1-3 \%)$ and low $\mathrm{Ca}$ counts, characterizes the modern Luvisol (unit a), whereas Ti, K, and Fe contents are relatively high. In contrast, the underlying units $\mathrm{b}$ to $\mathrm{g}_{2}$ show high carbonate contents (42-56\%) and $\mathrm{Ca}$ counts in agreement with the high TIC contents recorded in section I (Fig. 6), while Fe, K, and Ti decrease in these units. Below layer $\mathrm{g}_{3}$ the carbonate content drops to $10 \%$ and subsequently further decreases until values of around $1 \%$ are reached in horizon i. Decreased $\mathrm{Ca}$ and increased $\mathrm{Ti}, \mathrm{K}$, and Fe contents accompany the drop of carbonate values starting at the base of $\mathrm{g}_{3}$. In the basal gravel these trends reverse again and $\mathrm{Ti}, \mathrm{K}$, and $\mathrm{Fe}$ decrease while $\mathrm{Ca}$ increases (Fig. 7).

The grain-size distribution of the section shows increased clay content in the modern Luvisol (Fig. 7). In the underlying loess units the sand fraction increases and reaches maximum values in unit c. Below this unit, the sand fraction gradually decreases and reaches low values in unit $\mathrm{g}_{3}$ to $\mathrm{h}_{2}$. Unit $\mathrm{g}_{3}$ is also characterized by a high amount of clay, while the underlying units $\mathrm{h}_{1}$ and $\mathrm{h}_{2}$ contain almost exclusively silt. The sand and clay fractions increase again in unit $i$ and towards the top of unit $\mathrm{j}$. Finally, the coarse sand fraction as well as the clay fraction are increasing in unit $\mathrm{j}$. 


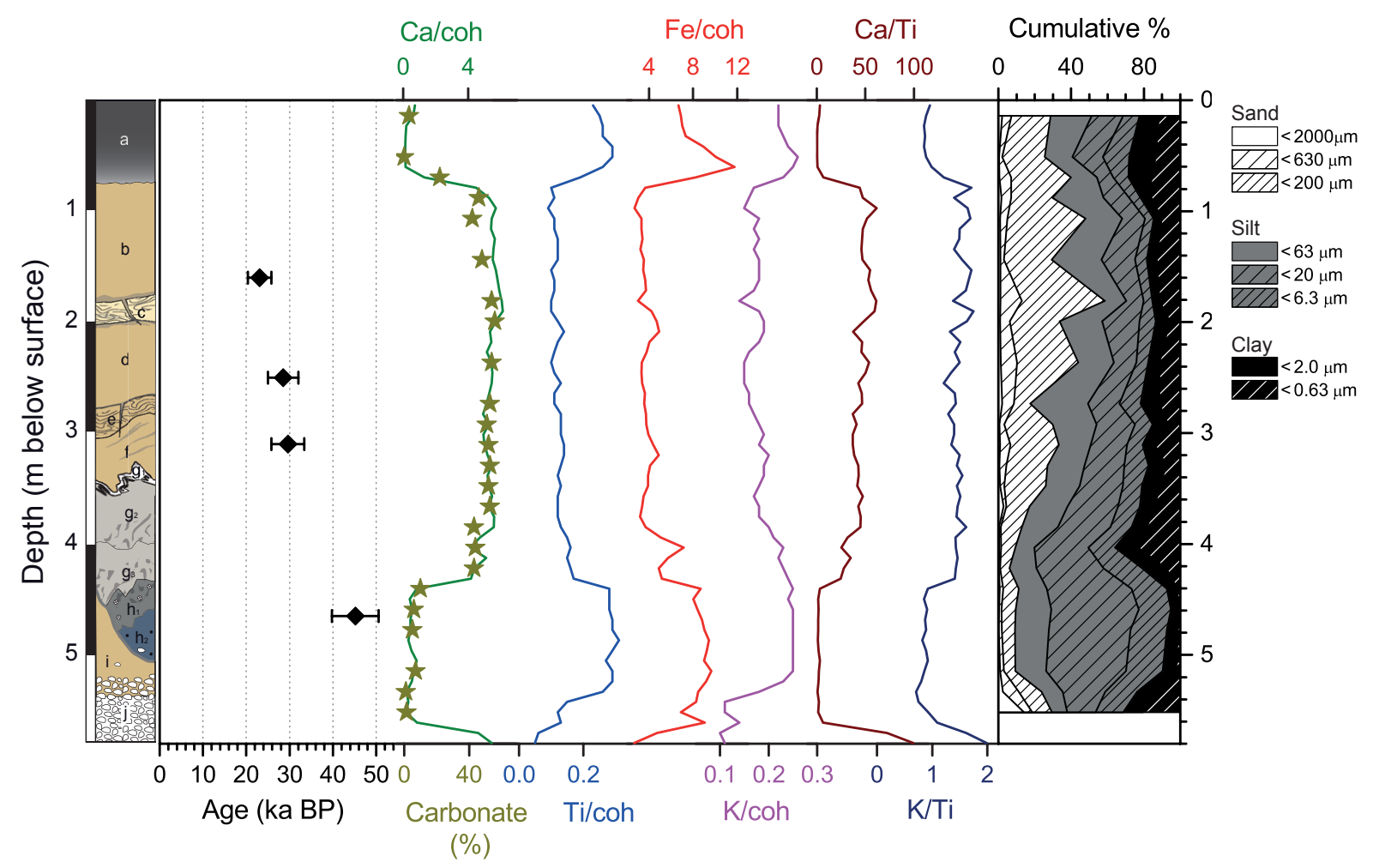

Figure 7. Element contents, grain-size distribution, and carbonate contents from section IV. The relative element contents derived from XRF analyses were divided by values of coherent radiation (coh) to account for matrix effects. Ages are interpolated from section III. Carbonate contents (stars) are plotted on top of the Ca curve to demonstrate the high accordance of both datasets.

\subsection{Vegetation record}

The pollen profile comprises the lithological unit $\mathrm{h}_{2}$ and the lowermost part of $h_{1}$. Grass taxa (Poaceae, Cyperaceae) dominate most of the pollen profile (Fig. 8). Among the arboreal pollen, Pinus is most abundant. The other arboreal taxon, Betula, occurs regularly, while Picea, Alnus, Corylus, and Salix as well as Hippophaë, Ephedra distachyatype, and E. fragilis-type were found only sporadically. Towards the top of the profile Juniperus, together with Pinus and Betula, becomes more frequent. Increased values of Cichorioideae in some stratigraphic levels are probably related to selective preservation of this resistant pollen type. The herbs Artemisia, Thalictrum, Brassicaceae, and Chenopodiaceae occur discontinuously throughout the profile. Aquatic macrophytes are represented by abundant pollen of the Ranunculus aquatilis group in the lower part of the profile peaking in unit $\mathrm{h}_{2}$, which is in accordance with the distribution of the chlorococcalean green algae Pediastrum and Botryococcus. All these aquatic taxa decrease towards the top. A single find of a seed of the Ranunculus aquatilis group from unit $\mathrm{g}_{3}$ (Fig. 9p) may indicate the presence of aquatic macrophytes also at a later time. Other aquatic macrophytes represented in the pollen record are Myriophyllum spicatum and M. alterniflorum. The pollen concentrations are very low in the whole profile and vary between 11 and 100 pollen grains in the sample volume of $5 \mathrm{~cm}^{3}$.

\subsection{Faunal remains}

The results of screening for microfossils are listed in Table 3 . Secondary carbonates were evident in all loessic units in the upper part of the profile except for unit $\mathrm{c}$ but were lacking in the layers below $\mathrm{g}_{2}$. Bivalves (Fig. 9a-d) only occurred in $\mathrm{g}_{2}$ and $\mathrm{g}_{3}$. Gastropods (Fig. 9e-o) were present in two groups of layers: an upper part including $\mathrm{c}, \mathrm{d}$, and e and a lower part comprising $\mathrm{g}_{1}, \mathrm{~g}_{2}$, and $\mathrm{g}_{3}$. Ostracods (Fig. 10) were found in layers $\mathrm{c}, \mathrm{g}_{1}, \mathrm{~g}_{2}$, and $\mathrm{g}_{3}$. Overall, the microfossil yield was low for most of the horizons, except for units $\mathrm{g}_{2}$ and $\mathrm{g}_{3}$, which provided enough specimens for statistical analyses. In all other layers, less than 30 specimens were found from each organism group; therefore these were not statistically evaluated. Bivalves were represented by Pisidium hibernicum. While in the upper part the gastropod assemblages consisted of a single species only (Succinella oblonga), the assemblages in the lower part were more diverse and included mainly aquatic species. The dominant gastropod taxon in $\mathrm{g}_{2}$ and $\mathrm{g}_{3}$ is Gyraulus acronicus with 78 and $60 \%$, respectively. The second- and third-most common species are Radix labiata and Valvata piscinalis alpestris 


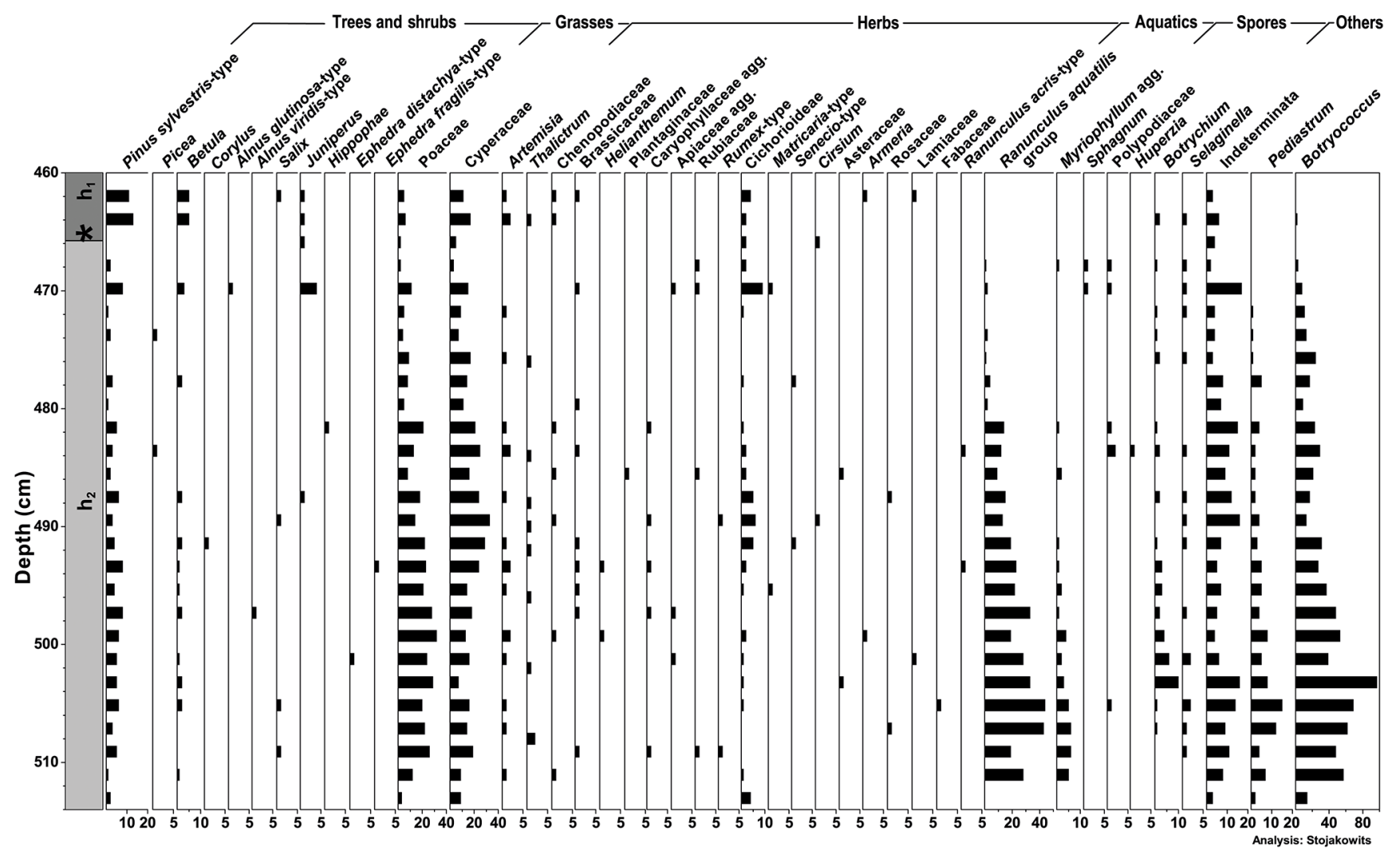

Figure 8. Pollen diagram of the monolith taken from unit $h_{2}$ and the base of $h_{1}$ in section IV showing the counted values from $5 \mathrm{~cm}^{3}$ of sediment. The asterisk marks the position of the OSL sample BOB-4. The landscape was characterized by open tundra-like vegetation with steppe elements and groups of shrubs.

in both units. In unit $\mathrm{g}_{3}$ Succinella oblonga is present with $5.5 \%$ while it is almost absent in $\mathrm{g}_{2}(0.8 \%)$. Limacidae and Anisus spirorbis occur in both units with less than $1 \%$. The ostracod assemblages in units $\mathrm{g}_{2}$ and $\mathrm{g}_{3}$ are mainly composed of Candona candida with 82 and $92 \%$, respectively. In unit $\mathrm{g}_{2}$ Limnocytherina sanctipatricii is the second-most dominating species $(13 \%)$ and in unit $\mathrm{g}_{3}$ Cyclocypris ovum (4\%). As a further taxon Pseudocandona sp. occurs with minor percentages in both units (Fig. 8).

Bones of micromammals were found in units $\mathrm{g}_{2}$ and especially in $\mathrm{g}_{3}$. Three teeth of the species Lemmus lemmus were identifiable (Fig. 9q). A fragment of a megamammal tooth found in unit $\mathrm{g}_{3}$ in section III most likely belonged to an equid.

\section{Discussion}

\subsection{Chrono-, bio-, and lithostratigraphic framework}

The uppermost part of the gravel deposits in the gravel pit directly adjacent to the NW to our sites at Bobingen provided OSL ages of $152 \pm 18$ and $160 \pm 53 \mathrm{ka}$ typical for the penultimate Rissian glaciation (Frechen, 1999). The palaeosoil remnants indicated by layer $\mathrm{j}$ in our profiles are corresponding to a Bt horizon described previously as remnants of a truncated brown forest soil (layer B in Frechen, 1999). It was suggested to be of Eemian age (Bibus, 1995; Becker-Haumann and Frechen, 1997). Our luminescence data cannot directly contribute to the question whether a sedimentation gap exists in the Bobingen LPS and whether the Lower Würm is entirely missing. A Lower Würmian hiatus, however, is likely, considering the small amount of sediment that, if sedimentation were continuous, would have been deposited from the brownish relic soil (unit j), attributed to an age of the end of the Eemian at $119 \mathrm{ka}$ (Rasmussen et al., 2014) until the layer containing our lowermost OSL date. This OSL date is at the transition of unit $h_{1} / h_{2}$ and provides an age of $45.2 \pm 5.4 \mathrm{ka}$. The Middle Würm lasted from 74 to $30 \mathrm{ka}$ (Preusser, 2004) and includes MIS 3 (59$29 \mathrm{ka}$; Voelker et al., 2002). Thus, the base of unit $\mathrm{h}_{2}$ is of Middle Würmian age.

Schielein and Schellmann (2016) recently mapped the Quaternary deposits in the Lech and Wertach valleys around Bobingen. They dated a LPS succession similar to the one described here located about $30 \mathrm{~m}$ west of it in an adjacent gravel pit. Their infrared stimulated luminescence (IRSL) age for a layer corresponding to units $h_{1} / h_{2}$ is $47 \pm 5 \mathrm{ka}$ and, 
Table 3. Semi-quantitative distribution of faunal remains in sections I and II.

\begin{tabular}{|c|c|c|c|c|c|c|c|c|c|c|c|c|c|}
\hline \multirow{2}{*}{$\frac{\text { Taxon }}{\text { Unit }}$} & \multicolumn{13}{|c|}{ Abundance* } \\
\hline & $\mathrm{b}$ & $\mathrm{c}$ & $\mathrm{d}$ & $\mathrm{e}$ & $\mathrm{f}$ & $\mathrm{g}_{1}$ & $\mathrm{~g}_{2}$ & $\mathrm{~g}_{3}$ & $\mathrm{~h}_{1}$ & $\mathrm{~h}_{2}$ & $i_{1}$ & $\mathrm{i}_{2}$ & $\mathrm{j}$ \\
\hline \multicolumn{14}{|l|}{ Gastropods } \\
\hline Succinella oblonga & 0 & 2 & 1 & 2 & 0 & 2 & 1 & 2 & 0 & 0 & 0 & 0 & 0 \\
\hline Anisus spirorbis & 0 & 0 & 0 & 0 & 0 & 0 & 1 & 1 & 0 & 0 & 0 & 0 & 0 \\
\hline Gyraulus acronicuss & 0 & 0 & 0 & 1 & 0 & 0 & 2 & 2 & 0 & 0 & 0 & 0 & 0 \\
\hline Radix labiata & 0 & 0 & 0 & 0 & 0 & 1 & 2 & 2 & 0 & 0 & 0 & 0 & 0 \\
\hline Valvata piscinalis alpestris & 0 & 0 & 0 & 0 & 0 & 0 & 2 & 2 & 0 & 0 & 0 & 0 & 0 \\
\hline Limacidae & 0 & 0 & 0 & 0 & 0 & 0 & 1 & 1 & 0 & 0 & 0 & 0 & 0 \\
\hline \multicolumn{14}{|l|}{ Ostracods } \\
\hline Candona candida & 0 & 2 & 0 & 0 & 0 & 1 & 2 & 2 & 0 & 0 & 0 & 0 & 0 \\
\hline Cyclocypris ovum & 0 & 0 & 0 & 0 & 0 & 0 & 1 & 1 & 0 & 0 & 0 & 0 & 0 \\
\hline Limnocytherina sanctipatricii & 0 & 2 & 0 & 0 & 0 & 0 & 2 & 1 & 0 & 0 & 0 & 0 & 0 \\
\hline Pseudocandona sp. & 0 & 0 & 0 & 0 & 0 & 0 & 1 & 1 & 0 & 0 & 0 & 0 & 0 \\
\hline \multicolumn{14}{|l|}{ Bivalves } \\
\hline Pisidium hibernicum & 0 & 0 & 0 & 0 & 0 & 0 & 1 & 1 & 0 & 0 & 0 & 0 & 0 \\
\hline \multicolumn{14}{|l|}{ Mammals } \\
\hline Lemmus lemmus & 0 & 0 & 0 & 0 & 0 & 0 & 1 & 2 & 0 & 0 & 0 & 0 & 0 \\
\hline Equus sp. & 0 & 0 & 0 & 0 & 0 & 0 & 0 & 1 & 0 & 0 & 0 & 0 & 0 \\
\hline
\end{tabular}

* Abundance categories listed are absent ("0", $N=0$ ), rare ("1", $0<N \leq 4$ ), and frequent ("2", $N>4$ ). The number of specimens $(N)$ is related to a sediment volume of about $1000 \mathrm{~cm}^{3}$.

thus, excellently matches our dating result. The underlying stratum, corresponding to unit $\mathrm{i}$ in our section, was thicker and more structured there. It provided an IRSL date of $59 \pm 9 \mathrm{ka}$ reaffirming the Middle Würmian age of the lower part of the LPS section (Schielein and Schellmann, 2016).

The almost complete lack of clay during the deposition of unit $\mathrm{h}_{1}$ and $\mathrm{h}_{2}$ may point to changing morphodynamic conditions during that time possibly related to higher wind speed or higher availability of clastic material from local (i.e. proximity of Wertach and Lech valleys) or regional sources. The palynological data of unit $h_{2}$ and the base of $h_{1}$ confirm the lack of Early Würmian strata and thus a hiatus. The Early Würm of the Füramoos pollen record from the northern Alpine foreland contains a markedly higher amount of Picea and Pinus pollen (Müller et al., 2003) than our pollen record. Thus, the units $h_{1}$ and $h_{2}$ were definitely deposited after the Early Würm. These units are also decalcified (Fig. 7) and thus indicate soil formation. A relative increase in $\mathrm{Ti}$ and $\mathrm{Fe}$ is contrasted by a decrease in $\mathrm{Ca}$ in these units. $\mathrm{Ti}$ is not affected by varying redox conditions (Haug et al., 2001) and increases with the concentration of weatheringresistant minerals. The similarity of $\mathrm{Fe}$ and $\mathrm{Ti}$ records (Fig. 7) suggests weathering as a predominant process for the enrichment of $\mathrm{Fe}$ in our sections. In contrast, $\mathrm{Ca}$ is removed by pedogenesis due to elution and decalcification, making the $\mathrm{Ca}$ / Ti ratio a primary weathering proxy (Fischer et al., 2012). However, Ca can also be re-precipitated as secondary carbonates. $\mathrm{K}$ is an element that is also easily eluted, and thus the $\mathrm{K} / \mathrm{Ti}$ ratio serves as an additional weathering proxy (Fischer et al., 2012). The similar courses of $\mathrm{K} / \mathrm{Ti}$ and $\mathrm{Ca} / \mathrm{Ti}$ (Fig. 7) confirm these considerations. As a consequence, the low $\mathrm{K} / \mathrm{Ti}$ and $\mathrm{Ca} / \mathrm{Ti}$ ratios of units $\mathrm{h}_{1}, \mathrm{~h}_{2}$, and $\mathrm{i}$ indicate similarly strong weathering as in the modern soil (unit a) as a result of pedogenesis. The greyishbluish colour preserved in units $\mathrm{h}_{2}$ to $\mathrm{g}_{2}$ in sections II, III, and IV, but not in section I, points to a gleyic soil horizon formed under water-saturated conditions. The frequently occurring aquatic palynomorphs in the pollen record of this layer support this interpretation. The absence of reduced features at the base of section I is likely related to secondary oxidation indicated by the ferruginous crust irregularly intersecting the bases of the sections (Fig. 3).

Bibus (1995) assigned a rubiginous, silty loam exposed at an adjacent loess section at Bobingen to the Böckingen soil. This horizon had approximately the same stratigraphic position as units $h_{1}$ and $h_{2}$ and was overlain by a loamy horizon with an olive tint that was attributed to the Lohne soil (Bibus, 1995). However, neither attributions was documented by independent dating methods at that time. Indeed, the age of $h_{1}$ and $h_{2}$ is approximately time-equivalent to the so-called Böckingen soil, originally described as a cambic soil horizon from the Neckar area in southern Germany (Bibus, 2002). The Böckingen soil was dated with luminescence methods to ca. $45 \mathrm{ka}$ in southern Germany and Austria (Frechen, 1999; 


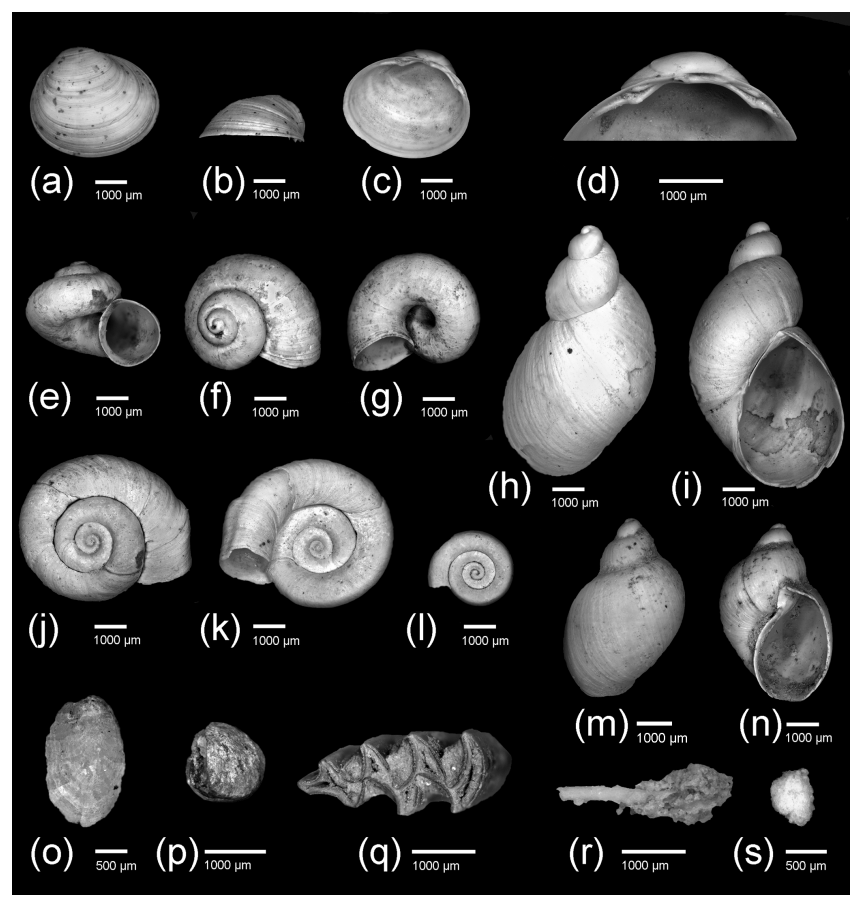

Figure 9. Bivalves, gastropods, and other fossil remains extracted from e (h, i, r), $g_{1}(\mathbf{s}), g_{2}(\mathbf{l})$, and $g_{3}(\mathbf{a}-\mathbf{g}, \mathbf{j}, \mathbf{k}, \mathbf{m}-\mathbf{q})$. All fossils are from section II except (s) (section I). (a-d) Pisidium hibernicum: right valve exterior (a), lateral (b), interior (c), and hinge area (d). (e-f) Valvata piscinalis alpestris. (h, i) Succinella oblonga. (j, k) Gyraulus acronicus. (l) Anisus spirorbis. (m, n) Radix labiata. (o) Limacidae indet. (p) Seed of Ranunculus aquatilis. (q) Lemmus lemmus. (r) Example of secondary carbonates: partly exposed carbonate coating inside hypocoating. (s) Earthworm biospheroid. Scale bars for $(\mathbf{o}, \mathbf{s}): 500 \mu \mathrm{m}$ and for $(\mathbf{a}-\mathbf{n}, \mathbf{p}-\mathbf{r}) 1000 \mu \mathrm{m}$.

Terhorst et al., 2002, 2015) and is considered to be timeequivalent to the Hengelo interstadial in northern Germany (Frechen 1999). However, the pedogenic features of a cambic soil horizon, in particular a brownish pigmentation, are not fulfilled for the units $h_{1}$ and $h_{2}$ in our profile. Instead gleyic features dominate both units. The 32 to $28 \mathrm{ka}$ old Lohne soil is overlying the Böckingen soil in many loess sections in central Europe (Terhorst et al., 2015). In this context it should be mentioned that according to new data the Lohne soil probably evolved during several Greenland Interstadials. Nevertheless, it is still a valuable pedostratigraphic marker (Sauer et al., 2016). It is possible that units $\mathrm{g}_{3}$ to $\mathrm{g}_{1}$ are timeequivalent to this soil, but, as outlined below, they are not primarily pedogenic but of lacustrine origin at our site.

The OSL date of $29.6 \pm 3.8 \mathrm{ka}$ in the centre of unit $\mathrm{f}$ indicates that this unit was deposited around or shortly after the transition from the Middle to the Upper Würm. The age of unit $\mathrm{d}$ is only about $1 \mathrm{kyr}$ younger than that of unit $\mathrm{f}$ when the average values of age determinations without error margins are considered. This would indicate that the sedimentation rate in the upper part of the section had

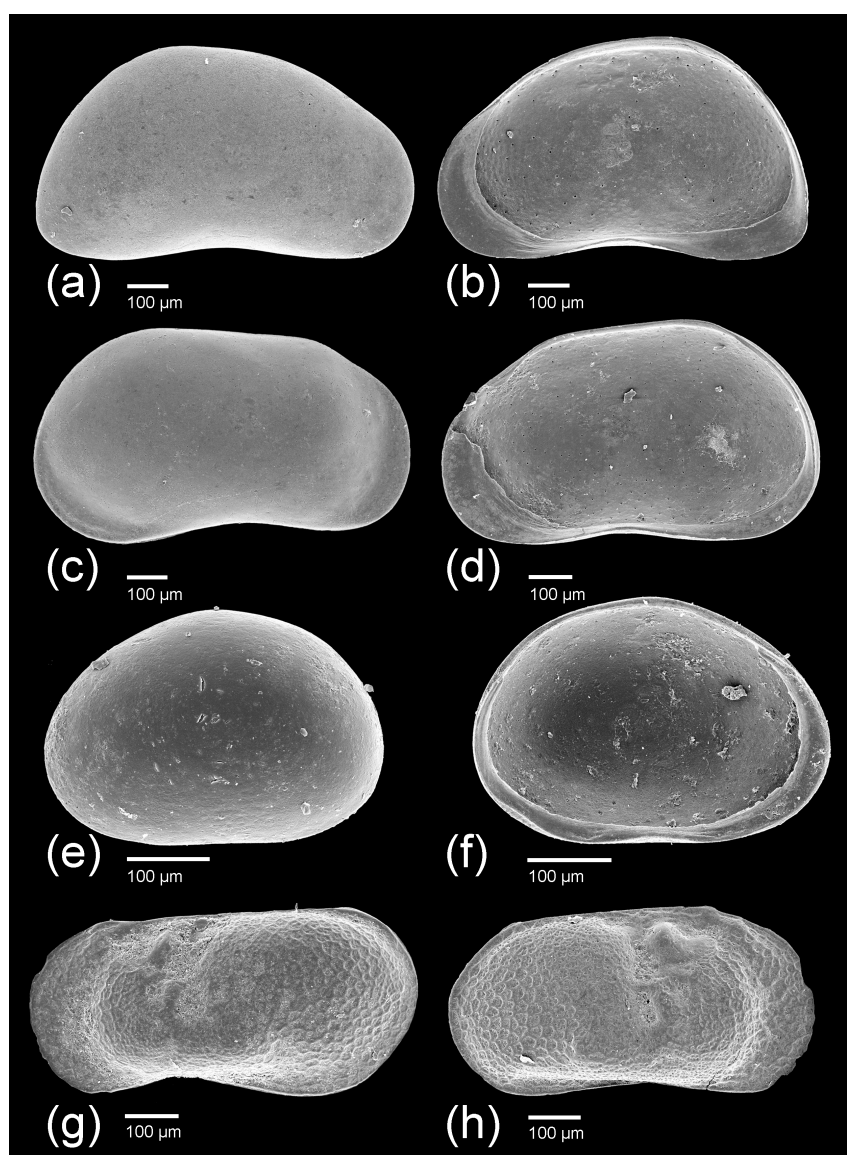

Figure 10. Scanning electron micrographs of ostracod species extracted from section II (g2 and g3). (a, b) Candona candida: right valve exterior (a) and interior (b). (c, d) Pseudocandona sp.: right valve exterior (c) and interior (d). (e, f) Cyclocypris ovum: left valve exterior (e) and interior (f). (g, h) Limnocytherina sanctipatricii: male left valve exterior (g) and female right valve exterior (h). Scale bars $100 \mu \mathrm{m}$.

increased substantially due to enhanced loess deposition. The uppermost age of unit b $(23.1 \mathrm{ka})$ is centred in the Last Glacial Maximum (LGM, 26.5-18.5 ka; Clark et al., 2009; Wirsig et al., 2016). Accordingly, full glacial conditions persisted during the deposition of unit $b$. In the area around Regensburg, about $120 \mathrm{~km}$ northeast of Bobingen, the accumulation of loess ended in the Oldest Dryas at $16.5 \mathrm{ka}$ based on luminescence dating (Buch and Zöller, 1990).

\subsection{Palaeoenvironmental reconstruction}

\subsubsection{Middle Würm}

As outlined above, the Middle Würm covers MIS 3 and is represented by the units $j$ to $f$ in our sections. The pollen spectra from units $h_{1}$ and the base of $h_{2}$ point to an open tundra-like vegetation consisting of steppe elements (e.g. Artemisia, Chenopodiaceae, Helianthemum, Thalictrum), Poaceae, some Cyperaceae, and many herbs. At some places 
shrub formations consisting of Juniperus, Salix, and probably a few pine (Pinus sylvestris) and birch (Betula) trees occurred in the further surroundings. The open vegetation, which grew under relatively cold climatic conditions, is also indicated by Botrychium and Selaginella selaginoides as well as by low pollen concentrations. Water plants (Ranunculus aquatilis group, Myriophyllum spicatum, and M. alterniflorum) and Cyperaceae dominated the local vegetation and have grown at the edges of a stagnant water body or a slow-flowing stream. These strata might reflect a climatic change related to short-term warming events commonly known as DansgaardOeschger events or Greenland interstadials (GI) from the Greenland ice cores. Twenty-five of these warming events are known for the last glacial period (Rasmussen et al., 2014). Temperature increases of up to $15^{\circ} \mathrm{C}$ in a few centuries were reconstructed during MIS 3 for these warm phases in Greenland (Huber et al., 2006). The most likely corresponding equivalent for the warm phase reflected in the pollen record of Bobingen is the relatively long period of warm events that started with GI-14 at $54.2 \mathrm{ka}$ and lasted until GI-12 at $44.3 \mathrm{ka}$ (Rasmussen et al., 2014).

The stagnant water body already present in units $h_{1}$ and $\mathrm{h}_{2}$ persisted or even extended during the sedimentation of $\mathrm{g}_{3}$ and $\mathrm{g}_{2}$, as aquatic faunal remains indicate. In units $\mathrm{g}_{3}$ and $\mathrm{g}_{2}$, the sphaeriid bivalve Pisidium hibernicum points to a lentic water body (Zettler and Glöer, 2006). This palaearctic species has been described as titanoeuryplastic (Meier-Brook, 1975).

Aquatic gastropods (Gyraulus acronicus, Radix labiata, Valvata piscinalis alpestris) occur frequently in units $\mathrm{g}_{3}$ and $\mathrm{g}_{2}$. The Holarctic species Gyraulus acronicus presently inhabits lakes, ponds, swamps, and pools (Ložek, 1964; Glöer and Meier-Brook, 2003). Anisus spirorbis is present in small stagnant temporary water bodies and swamps, whereas Radix labiata additionally occurs in slowly flowing water bodies (Glöer and Meier-Brook, 2003). The boreal-Alpine gastropod Valvata piscinalis alpestris is common in larger ponds and streams with muddy sediment (Ložek, 1964). The aquatic gastropod fauna is complemented by remains of terrestrial Limacidae and by the species Succinella oblonga. Both taxa are euryoecious. Limacidae occur in warm and wet vegetation-covered habitats with open areas like humid grasslands, open forests, swamps, and brooks (Ložek, 1964; Danukalova et al., 2015). Succinella oblonga is a "damp species" that inhabits wet places with sparse vegetation such as humid grasslands and swampy areas (Ložek, 1990; Moine et al., 2005).

Ostracods also confirm the existence of a water body during the deposition of units $\mathrm{g}_{3}$ and $\mathrm{g}_{2}$ and to a lesser extent in unit $\mathrm{g}_{1}$. The ostracod species Candona candida is nowadays common in habitats with a broad range of $\mathrm{pH}$ and salinity (Meisch, 2000). The species is oligothermophilic and typical for stagnant water bodies with lower temperatures, often influenced by cold groundwater inflows (Absolon, 1973; Fuhrmann, 2012). In the sedimentary context, its valves are predominantly found in lake marls and to a lesser extent in brook, spring, and peat deposits (Absolon, 1973). The ostracod Limnocytherina sanctipatricii, a coldstenothermal form, is typical for deeper lakes (Absolon, 1973), where it lives in depths up to $250 \mathrm{~m}$ (Löffler, 1969) and less frequently in smaller permanent water bodies such as swampy ponds and small creeks (Meisch, 2000). In central Europe, it presently prefers the cooler profundal areas of lakes but is supposed to have inhabited shallower stagnant water bodies during the last glacial period (Fuhrmann, 2012). Cyclocypris ovum is a rather euryoecious species that is reported frequently from the littoral zones of lakes and less from temporary pools and springs (Meisch, 2000). The species prefers permanent and stagnant water bodies with cool water temperature (Fuhrmann, 2012).

All three ostracod species have been previously identified from lacustrine sediments of southern Germany as typical members of Würmian ostracod assemblages, the so-called candida fauna (Absolon, 1973). Absolon grouped roughly a dozen species (with Cyclocypris ovum and L. sanctipatricii being two of them) around Candona candida as the leading elements in these assemblages. This candida fauna was opposed to the so-called cordata fauna, referring to the thermoeuryplastic species Metacypris cordata and its accompanying species, typical for the warmer Holocene climate and related higher productivity in lakes. The shift from candida fauna to cordata fauna has ever since been recorded as indicative for the transition from the last glacial period to the Holocene in central Europe (Günther, 1986; Griffiths and Holmes, 2000; Meisch, 2000).

The ostracods in the Middle Würmian lacustrine deposits at Bobingen, although not rich in species, represent a typical last glacial lacustrine fauna. It points to the presence of a small but persistent stagnant water body, which possibly developed in an inactive fluvial channel or in patterned ground during comparatively mild and humid periods of the Würm. Fluvial channels are recognizable by slight topographic differences in the digital elevation model (Fig. 2) and were outlined as polygenetic valley fillings of Pleistocene to Holocene age by Schielein and Schellmann (2016). Their south-north orientation and their position on the surface of the Rissian high terrace imply that they were formed before the LGM. Already Bibus (1995) mentioned that the gravel pit of Bobingen is located close to a former, now refilled, depression.

The organic carbon content of typical glacial loess deposits in northwestern Europe is less than $0.1 \%$. Thus, TOC values of the Middle Würmian strata are above average and similarly high as reported for interstadial palaeosoils of the same age at the Czech loess site Dolní Vestonice (Antoine et al., 2013). Thus, the increased TOC values peaking around unit $\mathrm{g}_{3}$ could indicate organic carbon accumulation during a period of climatic amelioration in the Middle Würm. Alternatively, the higher TOC values were caused by better preservation conditions of organic matter under 
waterlogged conditions (Zech et al., 2013). The $\delta^{13} \mathrm{C}_{\text {org }}$ values are another indicator for climatic changes during loess deposition. $\delta^{13} \mathrm{C}_{\text {org }}$ values between -26 and $-23 \%$ were recorded from European loess deposits. During periods of higher organic carbon deposition lower values were recorded (Antoine et al., 2013), a pattern similar to our record (Fig. 6). Apparently wetter and milder periods led to higher productivity and organic carbon deposition in combination with lower $\delta^{13} \mathrm{C}_{\text {org }}$ values. Indicators of permafrost occur, especially towards the end of the Middle Würmian deposits, when TOC values decrease and $\delta^{13} \mathrm{C}_{\text {org }}$ values increase. In particular, unit $\mathrm{g}_{1}$ is heavily affected by cryoturbation that has occurred during or shortly after deposition.

In summary, the Bobingen profile contains a diverse lacustrine Middle Würmian faunal assemblage that indicates a relatively mild climate. It represents one of the very few lacustrine records of Middle Würmian age in the Northern Alps and their foreland (Heiri et al., 2014).

\subsubsection{Upper Würm}

The Upper Würm approximately corresponds to MIS 2 and comprises the units $f$ to $b$. The stagnant water body persisted until shortly before the end of the Middle Würm. In unit $\mathrm{f}$, dated at around $30 \mathrm{ka}$, no lacustrine zoological indicators are found anymore and a typical loess deposition started. However, a few findings of Gyraulus acronicus in unit e and of the ostracod taxa Candona candida and Limnocytherina sanctipatricii in unit $\mathrm{c}$ indicate the return of stagnant water bodies during these short episodes directly before 29 and $23 \mathrm{ka}$ BP, respectively. Since the species L. sanctipatricii is restricted to stagnant and permanent water bodies (no resting eggs), an influx of live specimens from and by rivers of nearby valleys can be excluded. A redeposition of dead and fossil material from putative nearby stagnant water bodies is highly unlikely due to the presence of juvenile and adult valves in our samples (lack of sorting effects) and the high quality of preservation. The bleaching of horizons e and c was the result of redoximorphic processes under permanent waterlogging (Terhorst et al., 2014). Such horizons were commonly interpreted as tundra-gley soils, Gelic Gleysols, or Cryosols (Frechen, 1999; Antoine et al., 2009; Terhorst et al., 2014; Lehmkuhl et al., 2016). Regionally they are also called Nassböden, and up to six of these horizons were reported as Erbenheim soils in western Germany (Semmel, 1968; Lehmkuhl et al., 2016). The presence of sporadic lacustrine ostracod and gastropod species in these layers at the Bobingen site, in conjunction with pedogenic features such as bleaching (Fig. 3), could indicate warmer climatic conditions. This interpretation is in agreement with observations at the Nussloch site in southwestern Germany. Incipient soil formation combined with reduced aeolian sediment deposition at that site was related to climatic ameliorations equivalent to the short Greenland interstadials (Antoine et al., 2009). GI-4 and GI-
2 at 28.9 and $23.3 \mathrm{ka}$, respectively, are possible candidates for the warming events observed in our record. However, age uncertainties do not allow a definite correlation. Other GIs than the ones mentioned may not be recorded in our Upper Würmian record because of hiatuses or inadequate temporal resolution, issues which also challenge the interpretation of other loess sections (e.g. Lehmkuhl et al., 2016). Ice wedge pseudomorphs cutting through units $\mathrm{c}$ and $\mathrm{e}$ indicate sudden cooling under periglacial conditions soon after deposition of these layers.

\section{Conclusions}

In summary, the Bobingen outcrop contains a Middle and Late Würmian LPS intercalated by lacustrine layers. A gleyic soil developed during MIS 3 around $45 \mathrm{ka}$ and provided a tundra-like palynoflora dominated by steppe elements, a few shrubs, as well as pine and birch. A stagnant water body persisted in this environment until shortly before $30 \mathrm{ka}$. This stagnant water body hosted submerged and floating aquatic macrophytes and a cool, temperate but not diverse ostracod and gastropod fauna. The environmental setting changed during the transition to the Upper Würm (MIS 2) when the water body disappeared and the gastropod fauna was reduced to a single terrestrial species (Succinella oblonga). However, two short milder episodes, represented by units $\mathrm{e}$ and $\mathrm{c}$, are indicated by tundra-gleyic features and the reoccurrence of lacustrine species. These relatively warmer periods are presumably related to warming events reported from Greenland ice cores, most likely to GI-4 and GI-2, respectively, based on OSL dates.

Data availability. Supplementary data are available from the database PANGAEA at https://doi.pangaea.de/10.1594/ PANGAEA.884265 (Mayr et al., 2017).

Competing interests. The authors declare that they have no conflict of interest.

Acknowledgements. We are much indebted to the company Lauter Sand Kies Beton $\mathrm{GmbH}$ in Bobingen, and in particular to the owner Benjamin Lauter. He supported our research by providing access to the gravel pit, arranged the excavation of the profile several times and financially supported the dating of the sedimentary sequence. We are also grateful to Ute Schmidt for assistance with the grain-size and carbonate-content analyses, to Sabine Stahl and Christian Ohlendorf for help with the XRF scanning, and to Clara Stefen and Lisa Mammitsch for determination of the micromammal teeth. We thank the participants of two workshops carried out in Bobingen and especially Gerhard Doppler, Manfred Frechen, Wolfgang Rähle, and Gerhard Schellmann for discussions on site. We acknowledge financial support by the German Research Foundation (DFG) to Renate Matzke-Karasz 
(MA 2118/3-1) and Christoph Mayr (MA 4235/10-1). We thank Manfred Frechen and an anonymous reviewer for their helpful reviews.

\section{References}

Absolon, A.: Ostracoden aus einigen Profilen spät- und postglazialer Karbonatablagerungen in Mitteleuropa, Mitteilungen der Bayerischen Staatssammlung für Paläontologie und historische Geologie, 13, 47-94, 1973.

Adamiec, G. and Aitken, M.: Dose-rate conversion factors: update, Ancient TL, 16, 37-50, 1998.

Aktas, A. and Frechen, M.: Mittel- bis jungpleistozäne Sedimente der Hochterrasse in der nördlichen Iller-Lech-Platte, Geologisches Institut der Universität zu Köln, Sonderveröffentlichungen, 82, 19-41, 1991.

Antoine, P., Rousseau, D.-D., Moine, O., Kunesch, S., Hatté, C., Land, A., Tissoux, H., and Zöller, L.: Rapid and cyclic aeolian deposition during the Last Glacial in European loess: a highresolution record from Nussloch, Germany, Quaternary Sci. Rev., 28, 2955-2973, 2009.

Antoine, P., Rousseau, D.-D., Degeai, J.-P., Moine, O., Lagroix, F., Kreutzer, S., Fuchs, M., Hatté, C., Gauthier, C., Svoboda, J., and Lisá, L.: High-resolution record of the environmental response to climatic variations during the Last Interglacial-Glacial cycle in Central Europe: the loess-palaeosol sequence of Dolní-Vestonice (Czech Republic), Quaternary Sci. Rev., 67, 17-38, 2013.

Barta, G.: Secondary carbonates in loess-paleosoil sequences: a general review, Cent. Eur. J. Geosci., 3, 129-146, 2011.

Becker-Haumann, R. and Frechen, M.: Vergleichende Lumineszenz-Datierungen mit IRSL und TL am Deckschichtenprofil Bobingen/Lechtal, Z. Geol. Wissenschaft., 25, 617-633, 1997.

Beug, H.-J.: Leitfaden der Pollenbestimmung für Mitteleuropa und angrenzende Gebiete, Pfeil, München, Germany, 542 pp., 2004.

Bibus, E.: Äolische Deckschichten, Paläoböden und Mindestalter der Terrassen in der Iller-Lech-Platte, Geologica Bavarica, 99, 135-164, 1995.

Bibus, E.: Zum Quartär im mittleren Neckarraum: Reliefentwicklung, Löß/Paläobodensequenzen, Paläoklima, Tübinger Geographische Arbeiten D, 8, 1-236, 2002.

Blackmore, S., Steinmann, J. A. J., Hoen, P. P., and Punt, W.: The Northwest European Pollen Flora, 65. Betulaceae and Corylaceae, Rev. Palaeobot. Palyno., 123, 71-98, 2003.

Boschi, C.: Die Schneckenfauna der Schweiz. Ein umfassendes Bild- und Bestimmungsbuch, Haupt, Bern/Stuttgart/Wien, 624 pp., 2011.

Brunnacker, K.: Der würmzeitliche Löß in Bayern, Geologica Bavarica, 19, 258-265, 1953.

Buch, M. and Zöller, L.: Gliederung und ThermolumineszenzChronologie der Würmlösse im Raum Regensburg, E\&G Quaternary Sci. J., 40, 63-84, 1990.

Chapot, M. S., Roberts, H. M., Duller, G. A. T., and Lai, Z. P.: A comparison of natural- and laboratory-generated dose response curves for quartz optically stimulated luminescence signals from Chinese Loess, Radiat. Meas., 47, 1045-1052, 2012.

Clark, P., Dyke, A. S., Shakun, J. D., Carlson, A. E., Clark, J., Wohlfarth, B., Mitrovica, J. X., Hostetler, S. W., and Marshall
McCabe, A.: The last glacial maximum, Science, 325, 710-714, 2009.

Clarke, G. C. S., Punt, W., and Hoen, P. P.: The Northwest European Pollen Flora, 51. Ranunculaceae, Rev. Palaeobot. Palyno., 69, 117-271, 2001.

Croudace, I. W., Rindby, A., and Rothwell, R. G.: ITRAX: description and evaluation of a new multi-function X-ray core scanner, in: New Techniques in Sediment Core Analysis, edited by: Rothwell, R. G., Special Publications, Geological Society, London, UK, 51-63, 2006.

Danukalova, G., Osipova, E., Khenzikhenova, F., and Sato, T.: The molluscs record: A tool for reconstruction of the Late Pleistocene (MIS 3) palaeoenvironment of the Bol'shoj Naryn site area (ForeBaikal region, Eastern Siberia, Russia), Quatern. Int., 355, 24 33, 2015.

Doppler, G., Kroemer, E., Rögner, K., Wallner, J., Jerz, H., and Grottenthaler, W.: Quaternary Stratigraphy of Southern Bavaria, E\&G Quaternary Sci. J., 60, 329-365, 2011.

Duller, G. A. T.: Distinguishing quartz and feldspar in single grain luminescence measurements, Radiat. Meas., 37, 161-165, 2003.

Faegri, K. and Iversen, J.: Textbook of Pollen Analysis, John Wiley and Sons, Chichester, UK, 328 pp., 1989.

Fischer, P., Hilgers, A., Protze, J., Kels, H., Lehmkuhl, F., and Gerlach, R.: Formation and geochronology of last interglacial to lower Weichselian loess/palaeosol sequences - case studies from the Lower Rhine Embayment, Germany, E\&G Quaternary Sci. J., 61, 48-63, 2012.

Frechen, M.: Upper Pleistocene loess stratigraphy in Southern Germany, Quat. Geochronol., 18, 243-269, 1999.

Fuhrmann, R.: Atlas quartärer und rezenter Ostrakoden Mitteldeutschlands, Altenburger Naturwissenschaftliche Forschungen, 15, 1-320, 2012.

Galbraith, R. F., Roberts, R. G., Laslett, G. M., Yoshida, H., and Olley, J. M.: Optical dating of single grains of quartz from Jinmium rock shelter, northern Australia. Part I: experimental design and statistical models, Archaeometry, 41, 339-364, 1999.

Glöer, P. and Meier-Brook, C.: Süsswassermollusken - Ein Bestimmungsschlüssel für die Bundesrepublik Deutschland, Deutscher Jugendbund für Naturbeobachtung, Hamburg, Germany, 134 pp., 2003.

Gregor H.-J.: Die Eiszeit in Bobingen. Neue Funde und Ergebnisse aus Kiesgruben der Fa. Lauter (Landkreis Augsburg, Bayern), Documenta Naturae, 191, 1-155, 2012.

Griffiths, H. I. and Holmes, J. A.: Non-marine ostracods and Quaternary palaeoenvironments, Quaternary Research Association, Technical guide, 8, 1-179, 2000.

Griffiths, H. I., Rouse, A., and Evans, J. G.: Processing freshwater ostracodes from archaeological deposits, with a key to the valves of the major British genera, Circaea, 10, 53-62, 1993.

Günther, J.: Ostracod fauna of Duvensee, an ancient lake in Northern Germany, Hydrobiologia, 143, 411-416, 1986.

Haug, G., Hughen, K. A., Sigman, D. M., Peterson, L. C., and Röhl, U.: Southward migration of the Intertropical Convergence Zone through the Holocene, Science, 293, 1304-1308, 2001.

Heiri, O., Koinig, K., Spötl, C., Barrett, S., Brauer, A., DrescherSchneider, R., Gaar, D., Ivy-Ochs, S., Kerschner, H., Luetscher, M., Moran, A., Nicolussi, K., Preusser, F., Schmidt, R., Schoeneich, P., Schwörer, C., Sprafke, T., Terhorst, B., and Tinner, W.: Palaeoclimate records $60-8 \mathrm{ka}$ in the Austrian and 
Swiss Alps and their forelands, Quaternary Sci. Rev., 106, 186205, 2014.

Huber, C., Leuenberger, M., Spahni, R., Flückiger, J., Schwander, J., Stocker, T.F., Johnsen, S., Landais, A., and Jouzel, J.: Isotope calibrated Greenland temperature record over Marine Isotope Stage 3 and its relation to $\mathrm{CH}_{4}$, Earth Planet. Sc. Lett., 243, 504519, 2006.

Koeniger, P., Barta, G., Thiel, C., Bajnóczi, B., Novothny, Á., Horváth, E., Techmer, A., and Frechen, M.: Stable isotope composition of bulk and secondary carbonates from the Quaternary loess-paleosol sequence in Süttö, Hungary, Quatern. Int., 319, 38-49, 2014.

Lai, Z.: Chronology and the upper dating limit for loess samples from Luochuan section in the Chinese Loess Plateau using quartz OSL SAR protocol, J. Asian Earth Sci., 37, 176-185, 2010.

Lehmkuhl, F., Zens, J., Krauß, L., Schulte, P., and Kels, H.: Loess-paleosol sequences at the northern European loess belt in Germany: Distribution, geomorphology and stratigraphy, Quaternary Sci. Rev., 153, 11-30, 2016.

Löffler, H.: Recent and subfossil distribution of Cytherissa lacustris (Ostracoda) in Lake Constance, Mitteilungen - Internationale Vereinigung für theoretische und angewandte Limnologie, 17, 240-251, 1969.

Lowick, S. E., Preusser, F., Pini, R., and Ravazzi, C.: Underestimation of fine grain quartz OSL dating towards the Eemian: Comparison with palynostratigraphy from Azzano Decimo, northeastern Italy, Quat. Geochronol., 5, 583-590, 2010.

Ložek, V.: Quartärmollusken der Tschechoslowakei, Rozpravy ústredního ústavu geologického, 31, 1-374, 1964.

Ložek, V.: Molluscs in loess, their paleoecological significance and role in geochronology - principles and methods, Quatern. Int., 7/8, 71-79, 1990.

Mayr, C., Matzke-Karasz, R., Stojakowits, P., Lowick, S. E., Zolitschka, B., Heigl, T., Mollath, R., Theuerkauf, M., Weckend, M.-O., Bäumler, R., and Gregor, H.-J.: Würmian loess section, Bobingen (Germany): pollen, XRF, geochemical data, PANGAEA, https://doi.org/10.1594/PANGAEA.884265, 2017.

Meier-Brook, C.: Der ökologische Indikatorwert mitteleuropäischer Pisidium-Arten (Mollusca, Eulamellibranchiata), Eiszeitalter und Gegenwart, 26, 190-195, 1975.

Meisch, C.: Freshwater Ostracoda of Western and Central Europe, in: Süsswasserfauna von Mitteleuropa, edited by: Schwoerbel, J. and Zwick, P., vol. 8/3, 1-522, Spektrum Akademischer Verlag, Heidelberg, Germany, 2000.

Mejdahl, V.: Internal radioactivity in quartz and feldspar grains, Ancient TL, 5, 10-17, 1987.

Moine, O., Rousseau, D.-D., and Antoine, P.: Terrestrial molluscan records of Weichselian Lower to Middle Pleniglacial climatic changes from the Nussloch loess series (Rhine Valley, Germany): the impact of local factors, Boreas, 34, 363-380, 2005.

Moore, P. D., Webb, J. A., and Collinson, M.: Pollen Analysis, Blackwell, London, UK, 216 pp., 1991.

Moseley, G. E., Spötl, C., Svensson, A., Cheng, H., Brandstätter, S., and Lawrence Edwards, R.: Multi-speleothem record reveals tightly coupled climate between central Europe and Greenland during marine Isotope Stage 3, Geology, 42, 1043-1046, 2014.

Müller, G. and Gastner, M.: The "Karbonat-Bombe", a simple device for the determination of the carbonate content in sediments, soils and other materials, Neues Jahrbuch für Mineralogie/Monatshefte, 10, 466-469, 1971.

Müller, U. C., Pross, J., and Bibus, E.: Vegetation response to rapid climatic change in Central Europe during the past $140000 \mathrm{yr}$ based on evidence from the Füramoos pollen record, Quaternary Res., 59, 235-245, 2003.

Munsell Color: Munsell Soil Color Charts, Grand Rapids, USA, 2000.

Murray, A. S. and Wintle, A. G.: Luminescence dating of quartz using an improved single-aliquot regenerative-dose protocol, Radiat. Meas., 32, 57-73, 2000.

Murray, A. S. and Wintle, A. G.: The single aliquot regenerative dose protocol: potential for improvements in reliability, Radiat. Meas., 37, 377-381, 2003.

Ohlendorf, C.: A sample carrier for measuring discrete powdered samples with an ITRAX XRF core scanner, X-Ray Spectrom., 47, 58-62, 2017.

Penck, A.: Die Vergletscherung der Deutschen Alpen, Johann Ambrosius Barth, Leipzig, Germany, 483 pp., 1882.

Penck, A. and Brückner, E.: Die Alpen im Eiszeitalter, Tauchnitz, Leipzig, Germany, 1149 pp., 1901-1909.

Prescott, J. R. and Hutton, J. T.: Cosmic ray contributions to dose rates for luminescence and ESR dating: Large depths and longterm time variations, Radiat. Meas., 23, 497-500, 1994.

Preusser, F.: Towards a chronology of the Late Pleistocene in the northern Alpine Foreland, Boreas, 33, 195-210, 2004.

Preusser, F. and Kasper, H. U.: Comparison of dose rate determination using high-resolution gamma spectrometry and inductively coupled plasma-mass spectrometry, Ancient TL, 19, 17-21, 2001.

Rasmussen, S. O., Bigler, M., Blockley, S., Blunier, T., Buchardt, B., Clausen, H., Cvijanovic, I., Dahl-Jensen, D., Johnsen, S., Fischer, H., Gkinis, V., Guillevic, M., Hoek, W., Lowe, J., Pedro, J., Popp, T., Seierstad, I., Steffensen, J., Svensson, A., Vallelonga, P., Vinther, B., Walker, M., Wheatley, J. J., and Winstrup, M.: A stratigraphic framework for abrupt climatic changes during the Last Glacial period based on three synchronized Greenland ice-core records: refining and extending the INTIMATE event stratigraphy, Quaternary Sci. Rev., 106, 14-28, 2014.

Sauer, D., Kadereit, A., Kühn, P., Kösel, M., Miller, C., Shinonaga, T., Kreutzer, S., Herrmann, L., Fleck, W., Starkovich, B., and Stahr, K.: The loess-palaeosol sequence of Datthausen, SW/Germany: Characteristics, chronology, and implications for the use of the Lohne Soil as a marker soil, Catena, 146, 10-29, 2016.

Schaefer, I.: Geologische Karte von Augsburg und Umgebung 1:50000 mit Erläuterungen, Bayerisches Geologisches Landesamt, München, Germany, 92 pp., 1957.

Scheuenpflug, L.: Die risseiszeitliche Hochterrasse des Lechs nördlich Augsburg und die Schmutter (Bayerisch Schwaben), Heidelberger Geographische Arbeiten, 49, 194-209, 1979.

Schielein, P. and Schellmann, G.: Erläuterungen zur quartärgeologischen Karte 1:25000 des Wertachtals auf Blatt 7730 Großaitingen - Kartierungsergebnisse aus den Jahren 2014 und 2015, Bamberger Geographische Schriften, Sonderfolge, 12, 329-356, 2016.

Schielein, P., Schellmann, G., Lomax, J., Preusser, F., and Fiebig, M.: Chronostratigraphy of the Hochterrassen in the lower Lech 
valley (Northern Alpine Foreland), E\&G Quaternary Sci. J., 64, 15-28, 2015.

Schreiber, U. and Müller, D.: Mittel- und jungpleistozäne Ablagerungen zwischen Augsburg und Landsberg (Lech), Geologisches Institut der Universität Köln, Sonderveröffentlichungen, 82, 265-282, 1991.

Semmel, A.: Studien über den Verlauf jungpleistozäner Formung in Hessen, Frankfurter Geographische Hefte, 45, 1-133, 1968.

Starnberger, R., Terhorst, B., Rähle, W., Peticzka, R., and Haas, J. N.: Palaeoecology of Quaternary periglacial environments during OIS-2 in the forefields of the Salzach Glacier (Upper Austria), Quatern. Int., 198, 51-61, 2009.

Terhorst, B., Frechen, M., and Reitner, J.: Chronostratigraphische Ergebnisse aus Lößprofilen der Inn- und Traunhochterrassen in Oberösterreich, Z. Geomorphol. Supp., 127, 213-232, 2002.

Terhorst, B., Kühn, P., Damm, B., Hambach, U., Meyer-Hintze, S., and Sedov, S.: Paleoenvironmental fluctuations as recorded in the loess-paleosol sequence of the Upper Paleolithic site KremsWachtberg, Quatern. Int., 351, 67-82, 2014.

Terhorst, B., Sedov, S., Sprafke, T., Peticzka, R., Meyer-Heintze, S., Kühn, P., and Solleiro Rebolledo, E.: Austrian MIS 3/2 loess-palaeosol records - Key sites along a west-east transect, Palaeogeogr. Palaeocl., 418, 43-56, 2015.

Timar, A., Vandenberghe, D., Panaiotu, E. C., Panaiotu, C. G., Necula, C., Cosma, C., and Van den Haute, P.: Optical dating of Romanian loess using fine-grained quartz, Quat. Geochronol., 5, 143-148, 2010.

Voelker, A. H. L. and workshop participants: Global distribution of centennial-scale records for Marine Isotope Stage (MIS) 3: a database, Quaternary Sci. Rev., 21, 1185-1212, 2002.
Welter-Schultes, F.: European non-marine molluscs, a guide for species identification, Planet Poster Edition, Göttingen, Germany, 760 pp., 2012.

Wintle, A. G. and Murray, A. S.: Quartz OSL: Effects of thermal treatment and their relevance to laboratory dating procedures, Radiat. Meas., 32, 387-400, 2000.

Wintle, A. G. and Murray, A. S.: A review of quartz optically stimulated luminescence characteristics and their relevance in single-aliquot regeneration dating protocols, Radiat. Meas., 41, 369-391, 2006.

Wirsig, C., Zasadni, J., Christl, M., Akçar, N., and Ivy-Ochs, S.: Dating the onset of LGM ice surface lowering in the High Alps, Quaternary Sci. Rev., 143, 37-50, 2016.

Zander, A., Degering, D., Preusser, F., Kasper, H. U., and Brückner, H.: Optically stimulated luminescence dating of sublittoral and intertidal sediments from Dubai, UAE: Radioactive disequilibria in the uranium decay series, Quat. Geochronol., 2, 123-128, 2007.

Zech, M., Krause, T., Meszner, S., and Faust, D.: Incorrect when uncorrected: Reconstructing vegetation history using n-alkane biomarkers in loess-paleosol sequences - A case study from the Saxonian loess region, Germany, Quatern. Int., 296, 108-116, 2013.

Zettler, M. L. and Glöer, P.: Zur Ökologie und Morphologie der Sphaeriidae der Norddeutschen Tiefebene, Heldia, 6, 1-61, 2006.

Zöller, L. and Semmel, A.: 175 years of loess research in Germany - long records and "unconformities", Earth-Sci. Rev., 54, 19-28, 2001. 